\title{
Can Highway Networks Promote Productivity? Evidence from China
}

\author{
Yumei $\operatorname{Lin}^{1}$ and Junpei Huang $\mathbb{D}^{2}$ \\ ${ }^{1}$ School of Marxism, Shanghai University of International Business and Economics, Shanghai, China \\ ${ }^{2}$ School of Economics and Management, Tongji University, Shanghai, China \\ Correspondence should be addressed to Junpei Huang; 1830263@tongji.edu.cn
}

Received 16 July 2021; Accepted 30 October 2021; Published 22 November 2021

Academic Editor: Jing Dong

Copyright (c) 2021 Yumei Lin and Junpei Huang. This is an open access article distributed under the Creative Commons Attribution License, which permits unrestricted use, distribution, and reproduction in any medium, provided the original work is properly cited.

\begin{abstract}
The total mileage of highways in China ranks first in the world and constitutes an important symbol of China's modernization. Economists, however, continue to debate whether highways always promote economic growth in every region and how to assess the impact. In this paper, we first use the OD-MATRIX method to calculate the shortest highway traveling time among 332 prefecture-level cities in China from 2000 to 2013. It is shown that the reduction of traveling time brought by highway construction significantly improves enterprise productivity. Second, to further explore the mechanism at work, we apply market potential approach to examine its effect on productivity. It is found that on average, the enhanced market potential induced by highway construction in China positively affect enterprise productivity. Finally, we calculate urban centrality via the space gravity model and conduct a sample regression according to the rank of urban centrality. Interestingly, we find that the impact of highways on productivity varies depending on cities' degree of urban centrality. Highways have a positive impact in highcentrality cities but a negative impact in low-centrality cities. This correlation can be explained, in turn, by factors that include labor and capital flow from low-centrality cities to high-centrality cities.
\end{abstract}

\section{Introduction}

The launch of the Hujia Highway in 1988 and the Shenda Highway in 1990 initiated the development of China's highways (In China, highways are divided into five grades by function: expressways, first-grade highways, secondgrade highways, third-grade highways, and fourth-grade highways; in this paper, the term highway refers to an expressway with a tollgate). By 2018, the total distance of the national highway reached 142,600 kilometers, and a national highway network (71,118 nets) consisting of 7 capital radiation lines, 11 north-south vertical lines, and 18 east-west horizontal lines had been built. The total mileage is ranked first in the world, and the highway density in the eastern and central regions has exceeded that of major developed countries. The highway network extending in all directions is an important symbol of China's transportation modernization and an important core asset of the country and localities.
In contrast with highways in most other countries, about 95\% of China's highways are constructed with loans that are then repaid through toll charges. By 2017, the cumulative investment in highway construction throughout the country had reached RMB 7.63 trillion, and the debt balance reached RMB 5.0 trillion. Hence, the utilization rate of the highway after completion is an important issue. In 2013-2018, the annual national highway mileage increased by $8.3 \%$, but the average daily traffic volume only increased by $3.3 \%$. Both debt repayment and increased utilization depend, in the final analysis, on whether a highway has a positive effect on productivity. But does a highway have the same promotion effect on productivity in various regions? Practice suggests not. Highways have accelerated the accumulation of enterprises in some regions but facilitated the outflow of growth factors in other regions, thus further expanding regional differences $[1,2]$. The reason for this differential effect may be that highways have different degrees of influence on the productivity of different regions. Many 
studies have analyzed the importance of transportation infrastructure construction to productivity improvement, using theoretical models as well as empirical evidence [3, 4]. Based on the evidence from developed countries, some of the literature suggests that the impact of highways on productivity is different in different regions, and that highways even have a negative effect on certain regions $[1,2]$. In terms of the influence mechanisms by which highways affect productivity, most of the literature highlights the reduction of transportation costs and spatial spillover effects [5, 6]. Most of China's highways require drivers to pay a charge or toll, thus having the characteristics of fast transit speed, short travel time, and high transportation costs. These considerations raise further questions: How do Chinese highways affect the productivity of different regions? Which areas are positively affected, and which areas are negatively affected? Through what mechanisms do highways affect productivity in different regions? At present, studies addressing these questions are rare. And in the studies that do exist, mechanisms such as reduction of transportation costs and spatial spillover effects are not sufficient to explain why highways have different effects on productivity in different regions.

In this paper, in order to examine the impact of highway development on enterprise productivity, first, cutting through space-time compression effect, we use the OD-MATRIX to calculate highway travel time of 332 prefecture-level administrative cities. The results show that, on average, construction of the highway shortens the travel time between cities and reduces the transportation cost, thus improving enterprise productivity. Second, to further explore the mechanisms at work, we adopt a "market potential" approach. We improve the estimation method in Baum-Snow et al. [2], estimate the dynamic parameter $\beta$ using data for passenger capacity in various cities in China, measure how the construction of the highway network affects each city's "market potential," and estimate the impact of the enhanced market potential on enterprise productivity. We find that the market potential induced by highways has a significant positive impact on enterprise productivity. Third, we analyze the heterogeneity of the impact. We calculate the urban centrality by using the spatial gravity model and then conduct a sample regression according to the rank of urban centrality. Interestingly, it is that the highway in high-centrality cities has a positive impact on productivity, on the contrary, in cities ranked lower than 200 for centrality, highways have a negative impact on productivity. Further exploring the reasons for the heterogeneity, we find that the development of the highway network allows labor and capital to flow from a centrally weak city to a centrally strong city.

The main contributions of this paper include the following: First, drawing on Janelle's [7] "compression of time and space" theory, we adapt the OD-MATRIX method to measure the shortest travel time on highways in Chinese prefecture-level cities (The sample set used in this paper includes all the second-level local administrative regions in China, namely, municipalities, prefecture-level cities, autonomous prefectures, and leagues). We use this measure as an explanatory variable to establish a regression equation between highways and productivity. Second, in accordance with Donaldson's [8] approach, we treat market potential as an intermediary mechanism by which highways affect productivity. Some studies in the literature examine the changes in regional market potential caused by highways but rarely do these studies directly estimate the impact of market potential on productivity in the manner outlined here. Third, we improve on the Baum-Snow et al. [2] parameter estimation method through the market potential calculation formula of Chen and Haynes [9]. Relying on that formula, we calculate the market potential of each city by using the result of the regression estimation of the road impedance function-based on passenger volume data for different prefecture-level cities in China. Fourth, based on the spatial gravity model, we analyze urban centrality and characterize urban heterogeneity, conducting a sample regression to explore the different effects of highways on the productivity of different kinds of cities. We come to a conclusion different from that reached by other researchers, arguing that the impact of the highway on productivity is different depending on a city's degree of centrality. More specifically, highways have a positive influence on high-centrality cities and a negative influence on lowcentrality cities. Fifth, we verify Faber's [1] hypothesis concerning "core-periphery effects of trade integration between ex ante asymmetric markets"; that is, the opening of highways promotes an outflow of growth factors such as labor and capital from low-centrality cities to high-centrality cities.

\section{Literature Review}

The focus on the relationship between highways and productivity began with the discussion of the US "productivity crisis" that started in the early 1970s. According to this research, the productivity of the United States increased by $2.5 \%$ annually on average from 1948 to 1969 , whereas the average annual growth rate was $1.1 \%$ from 1969 to 1987 [10]. Some scholars referred to the low productivity growth rate of this period as the "productivity crisis" [11]. Scholars such as Baily et al. [12], Denison [13], and Griliches [14] attempted to explain what may have caused this productivity crisis, but their analyses were not widely accepted. Then, Aschauer [15] published a groundbreaking study hypothesizing that the decline in US public capital (or infrastructure) investment is the root cause of the decline in productivity growth rates, and that a $10 \%$ increase in public infrastructure stocks would improve the productivity of the private sector from $3 \%$ to $5.6 \%$. Since highways account for $32 \%$ of all public capital [16], its impact on productivity would be, on this model, quite significant.

In the decades following Aschauer's [15] study, researchers measured the contribution of highway investment to productivity and arrived at two diametrically opposite conclusions. The majority of the researchers concluded that highway investment has a positive effect on economic growth. Jiwattanakulpaisarn et al. [17], for example, measured the output elasticity of highways at +0.029 and +0.054 . Pereira and Andraz [18], Berechman et al. [19], and Ozbay et al. [20] found that highways have a positive impact on regional outputs. Holl [5] and Chakrabarti [21] conducted research on highways in Spain and India, respectively, and found that they have a positive effect on manufacturing 
productivity. Gao et al. [22] argued that highways have increased the productivity of China's service industry, and $\mathrm{Bu}$ et al. [23] suggest that highways correct for limitations of growth factors and increase productivity. At the same time, however, other researchers reached the opposite conclusion, finding that highway investments have no significant or even a negative impact on productivity growth. For their part, Eisner [24], Evans and Karras [25], and Garcia-Milà et al. [26] found no significant impact on productivity in their research on US state highways.

As for the mechanisms by which investment in highways affect productivity, most of the existing literature targets transportation costs and space spillover. For example, Shirley and Winston [27] and Datta [28] found that highways reduce the company's inventory and logistics costs. Duranton and Turner [29], Ghani et al. [30], and Holl [5] stated that highways yield savings on business travel costs and time, as well as a reduction of transportation costs, which all directly affect productivity. Other transportation scholars have focused on space spillovers. In the framework of spatial econometrics, Pereira and Andraz [18], Berechman et al. [19], Yu et al. [31], and Chen and Haynes [9] found, through empirical analysis, that highway investment has a positive space spillover effect. On the one hand, highways improve the supply chain and customer service by saving time, attract more enterprises to a given area, increase the scale or density of agglomeration, and generate agglomeration externalities such as knowledge spillover, a larger labor pool, and input sharing with neighboring enterprises. On the other hand, the reduced travel time enabled by highways creates labor mobility and allows growth factors to flow more rapidly, facilitating learning effects, matching effects, and sharing effects, and expanding the geographical range that an agglomeration economy may achieve-that is, expanding its "effective density," in Graham's [32] terms.

With regard to the relationship between highways and productivity, why do different researchers draw such divergent conclusions? Recently, some transportation scholars have criticized the methods of the earlier researchers, noting their failure to take into account the reverse-causality relationship between highways and outputs, their neglect of key analytic variables [16], and their failure to consider the time-lag effect of the highways [17] - with these methodological problems resulting in the divergent findings. Other researchers have addressed these issues from the perspective of space spillover effects. Highways may shift economic activity from one region to another, causing a positive spillover effect in some areas but a negative spillover effect in neighboring areas [33]. But this account begs another question: Which areas will experience a positive spillover effect from highways, and which a negative spillover effect? This question has yet to be answered satisfactorily.

\section{Data and Variables}

3.1. Main Explanatory Variable: Shortest Highway Travel Time between Cities. According to the "space-time compression" theory of Janelle [7], the most important impact of highways on regional development lies in the shortened travel time between cities. Therefore, in studying the relationship between highways and productivity, choosing the shortest travel time as the proxy variable for a given highway is more suitable than the traditional highway indicators such as mileage and density.

In order to calculate the shortest travel time on highways between cities, we established the digital maps of highways each year during the period 2000-2013. We first used ARCGIS to obtain and map the highway vectors during these years, and then used the latest version of China's highway network map for calibration. Next, we confirmed the speed of each highway segment. In the work of measuring highway travel time between two regions, the traveling speed is an important factor. In China, highways have speed limits, according to which the maximum speed should not exceed 120 kilometers per hour, and the minimum speed should not be lower than 60 kilometers per hour. Li and Shum [34], when calculating highway travel times, set the average speed of highways at 100 kilometers per hour and the average speed of national highways (The term national highways here refers to roads other than the expressways that are nonetheless classified as highways.) at 60 kilometers per hour. This simplified calculation method, however, fails to take into account different highway speed limits, and different speed limits will seriously affect the travel time between two regions. Therefore, when calculating the actual travel time between cities, it is necessary for transport speed to be accurately matched with each section of the road according to the speed limit for that particular section. For this paper, we used GPS navigation data from Amap to match the speed limit for each road section with the GIS map. Finally, we generated the digital maps of highways each year from 2000 to 2013 . We determined the opening dates for each highway since the opening of the first Shanghai-Jiading Highway in 1998 and then drew the digital map of the highway year by year using the subtraction method (see Figure 1).

In this study, we use the methods of Lin et al. [35] to calculate the shortest highway travel time. The shortest travel path between two regions was selected by using the shortest travel-time path rather than the shortest space path, so spatial distances had to be converted into temporal durations in our calculations. We matched the speed limit data of each road section with GIS map and used OD-matrix method to calculate the shortest travel time between cities. To do so, we built a road network between city $i$ and city $j$, and then set the speed of the road according to the speed limit for different sections. Afterwards, we calculated the actual travel time for each road section according to the mileage and transportation speeds. In the end, we selected the shortest travel path between city $i$ and city $j$ according to the calculated travel time. The highway travel time between city $i$ and city $j$ is the sum of the "time distance" of this route. The formula for calculating the shortest highway travel time between city $i$ and city $j$ is as follows:

$$
\text { time_dis } s_{i j}=\text { time_dis }_{i r_{1}}+\text { time_dis }_{j r_{2}}+\min \left(\text { time_dis }_{r_{1} r_{2}}\right) \text {. }
$$

The time distance between city $i$ and city $j$ is the travel time from the center of the city $i$ to the closest highway entrance $r_{1}$, 

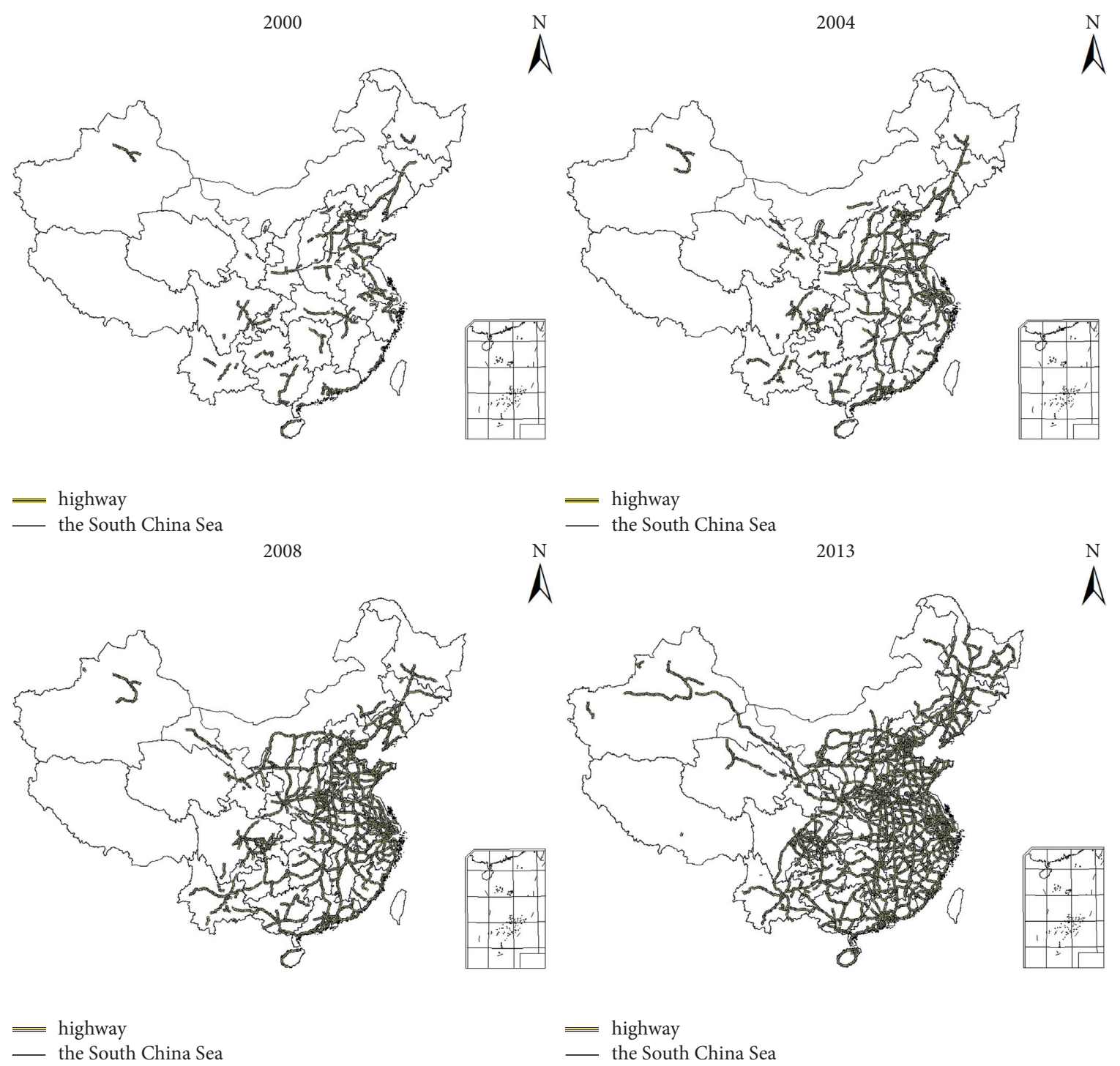

Figure 1: The highway layout of China in 2000, 2004, 2007, and 2013.

time_dis ${ }_{i r_{1}}$ plus the travel time from the center of the city $j$ to the closest highway entrance $r_{2}$, time_dis ${ }_{i r_{2}}$ plus the shortest travel-time distance between $r_{1}$ and $r_{2}$ after speed limits are factored in. In addition, since the highway network does not encompass all cities in China during the sample period (2000-2013), in order to avoid numerous missing data points, the national highway network in 2014 was also included in our digital map of the highway network. Thus, for the purposes of our study, travelers are assumed to travel on the national highway even in places where there is no highway, and the time distance is then calculated according to the speed limit of the national highway. Finally, we used to formula (2) to calculate the highway travel time for each city:

$$
T_{i}=\sum_{j=1}^{n-1} \text { time_dis }_{i j} .
$$

Table 1 reports the summary results for highway travel time. It can be seen that the highway network has significantly reduced the total cross-regional travel time in China.
Moreover, the travel time presents a typical "centerperiphery" distribution pattern. The Beijing-TianjinHebei area, the Yangtze River Delta area, and the middle reaches of the Yangtze River have the shortest travel times, and then travel times gradually increase when one moves from this central region to the periphery. The northwest region and some northeast regions have the longest travel times (Figure 2).

\subsection{Explained Variable: Enterprise Total Factor Productivity} (TFP). The data for measuring productivity at the enterprise level comes from the Chinese industrial enterprise database. China industrial enterprise database is established by the National Bureau of statistics, whose data mainly come from the quarterly and annual reports submitted by sample enterprises to the local statistical bureau. The sample range is all state-owned industrial enterprises and nonstate-owned industrial enterprises above scale, and its statistical unit is the business entity. The statistical caliber of "industry" includes 
TABLE 1: The shortest travel time for highways in China.

\begin{tabular}{lcc}
\hline Year & Average total travel time (in hours) per city & Average travel time between cities \\
\hline 2000 & 13671.23 & 41.1784 \\
2001 & 12664.46 & 38.1460 \\
2002 & 11985.27 & 36.1002 \\
2003 & 11227.63 & 33.8182 \\
2004 & 10889.99 & 32.8012 \\
2005 & 10411.30 & 31.3593 \\
2006 & 10150.54 & 30.5739 \\
2007 & 9778.00 & 29.4518 \\
2008 & 9025.746 & 27.1860 \\
2009 & 9031.845 & 27.2043 \\
2010 & 7332.246 & 22.0851 \\
2011 & 6899.249 & 20.7809 \\
2012 & 6466.252 & 19.4767 \\
2013 & 6367.426 & 19.1790 \\
\hline
\end{tabular}

three categories of mining industry, manufacturing industry, and production and supply of electricity, gas, and water in industry classification of national economy, mainly manufacturing industry (accounting for more than 90\%). "Above scale" here refers to the annual main business income (i.e. sales) of an enterprise is at or above 5 million yuan. Chinese industrial enterprise database is the most comprehensive enterprise database which includes two types of information: one is the basic situation of the enterprise, the other is the financial data of the enterprise [36]. According to the incomplete statistics of Google scholar database and Nie et al. [36], as of the end of 2016, more than 200 overseas academic papers have used China industrial enterprise database, where the published journals includes comprehensive journals such as Quarterly Journal of economics, American Economic Review, Review of Economic Studies, and Economic Journal, and disciplinary journals such as Journal of Development Economics, Journal of Urban Economics, etc. [37].

Before using, we process the data as follows: We follow the practice of Brandt et al. [38] who use the corporate legal person code, company name, legal person name, province and city code, legal representative name, telephone number, industry code, year of establishment, and main products to carry out multiple-field matching (hence, the unbalanced panel data for 2010-2013). Also, like Brandt et al. [38], we eliminate duplicate samples, and like Cai et al. [39] we threw out samples that lacked important information. Furthermore, we use the 2004 economic census data to fill in the missing values for gross industrial output in 2004, and the 2011 indicator of state capital to fill in missing values for 2009 and 2010. Finally, we follow Cai et al. [39] in measuring the missing industrial added value through the formula of industrial added value = industrial gross output - intermediate input + value-added tax.

To calculate the total factor productivity of firms, we construct the input-output indicators of those firms, including their actual net output level, their capital stock, their labor costs, and their intermediate input. We rely in the first instance on the method of Jian [40], using the industrial added value as the measure of the net output level of the enterprise, and averaging the industrial added value of the enterprise according to the industrial product mill price index of each province. Then, we use the perpetual inventory method to calculate the capital stock of the enterprise. We take the net value of the fixed assets of each enterprise in the year of its occurrence as the initial capital stock of the enterprise and reduce it to the initial value of the fixed asset investment price index of each province at the beginning of 2000; we use the same method to get the actual amount of depreciation per year. Finally, we use the industrial product mill price index of each province to adjust the intermediate input amount to the constant price in 2000 as the actual intermediate input amount of each enterprise.

The calculation methods of TFP include ordinary least squares (OLS), Fixed effect (FE), Olley-Pakes approach (OP), the Levnsohn-Petrin approach (LP), and GMM approach. Since the OP approach can avoid the endogeneity problem and sample selection bias occurring in other methods that can get more accurate estimation results [41], in this study, we use the OP method to calculate the enterprises total factor productivity.

Following the idea of Olley and Pakes [42]; we estimate the following model:

$$
\begin{aligned}
\ln Y_{i t}= & \beta_{0}+\beta_{k} \ln K_{i t}+\beta_{l} \ln L_{i t}+\beta_{a} \text { age }_{i t}+\beta_{s} \text { state }_{i t} \\
& +\beta_{e} E X_{i t}+\sum_{m} \delta_{m} \text { year }_{m}+\sum_{n} \lambda_{n} \text { reg }_{n}+\sum_{k} \xi_{k} \text { ind }_{k}+\varepsilon_{i t},
\end{aligned}
$$

where $Y_{i t}$ denotes industrial added value of enterprise $i$ in year $t, K$ and $L$ denote scale of fixed assets and employees, respectively, year ${ }_{m}, \operatorname{reg}_{n}$, and ind $d_{k}$ denote dummy variable of year, region, and industry, respectively. age ${ }_{i t}$ denotes the enterprise age, state $_{i t}$ denotes the dummy variable of whether the enterprise is state-owned, and $E X_{i t}$ denotes the dummy variable of whether the enterprise participates in export activities. We use O-P semi-parameter three-step approach to calculate the productivity and the result weighted average by region is shown in Figure 3.

3.3. Mechanism Variable: Market Potential. The concept of market potential can be traced back to Harris [43] who measured the potential market that a region can obtain 


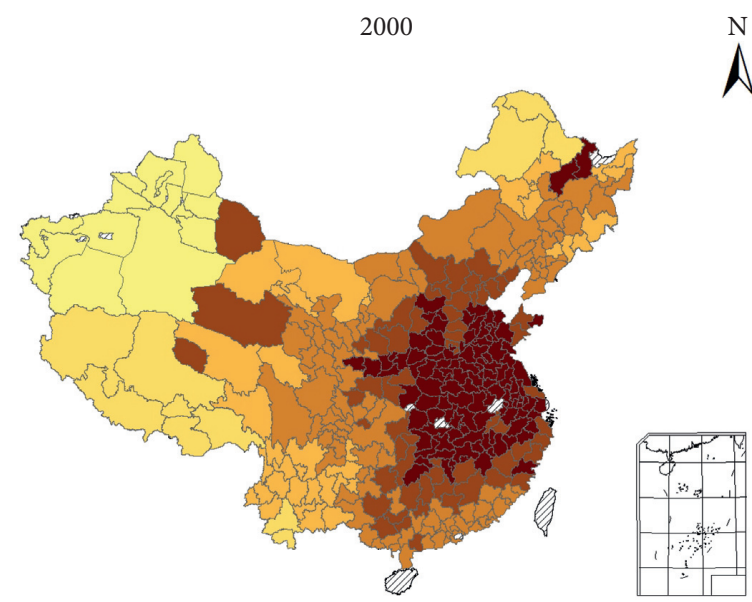

$\stackrel{N}{\Lambda}$

2004

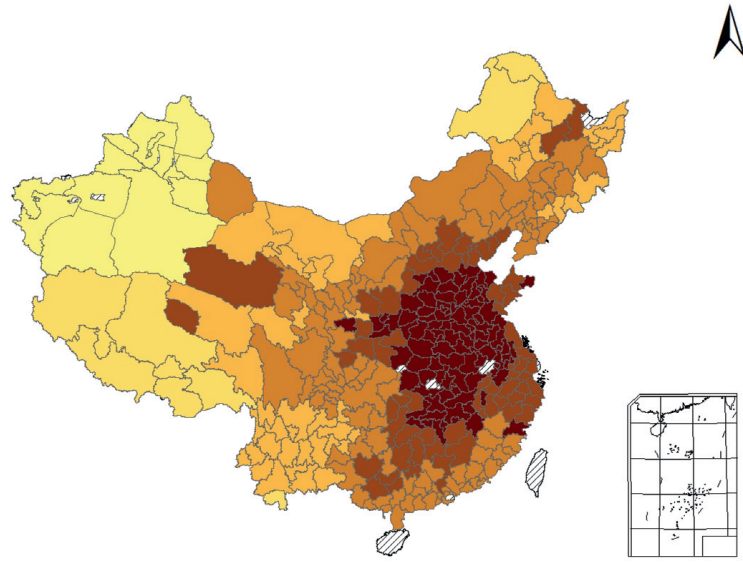

travel time

travel time

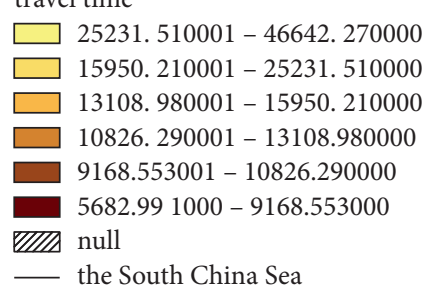

2008

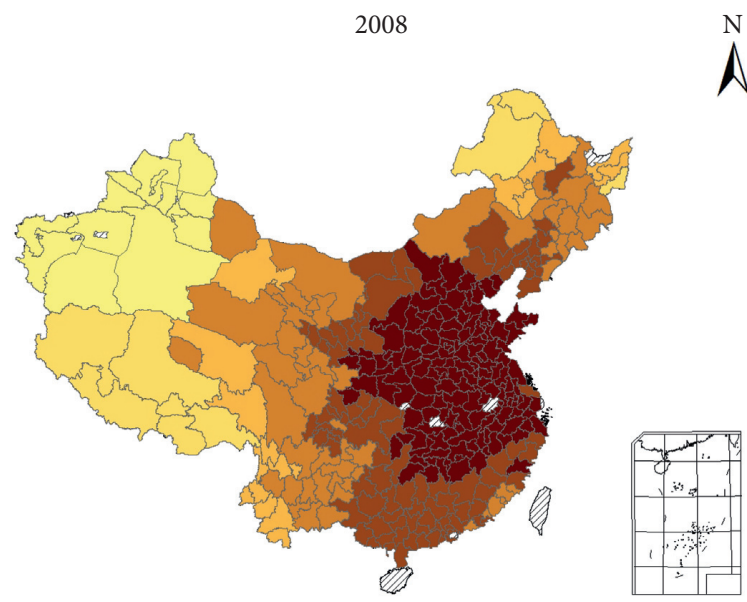

$\stackrel{N}{N}$
$\stackrel{N}{\Lambda}$ $\square$ 24416.610001 - 45827.360000
$\square$ 14662.070001 - 24416.610000
$\square 1639.650001-14662.070000$
$9424.096001-11639.650000$
$7983.817001-9424.096000$
$5682.991000-7983.817000$
$\square$ null
$\square$ the South China Sea

2013

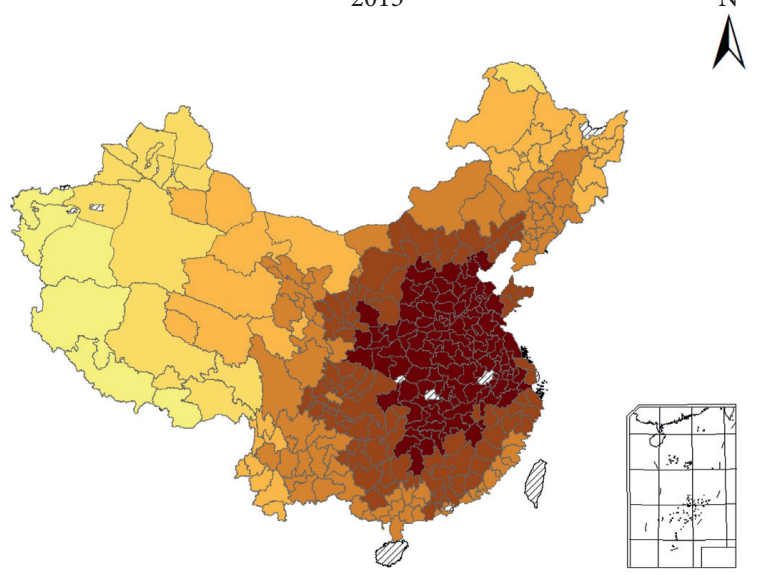

travel time

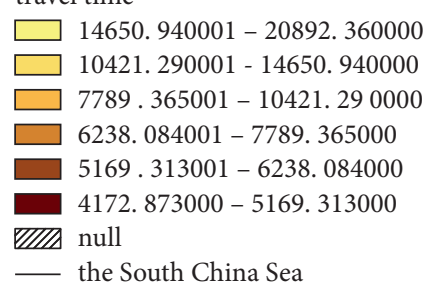

travel time

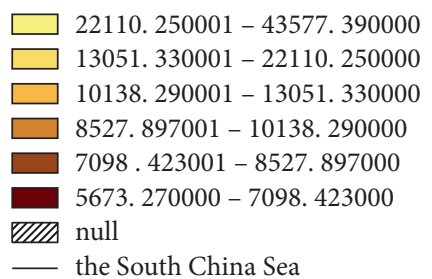




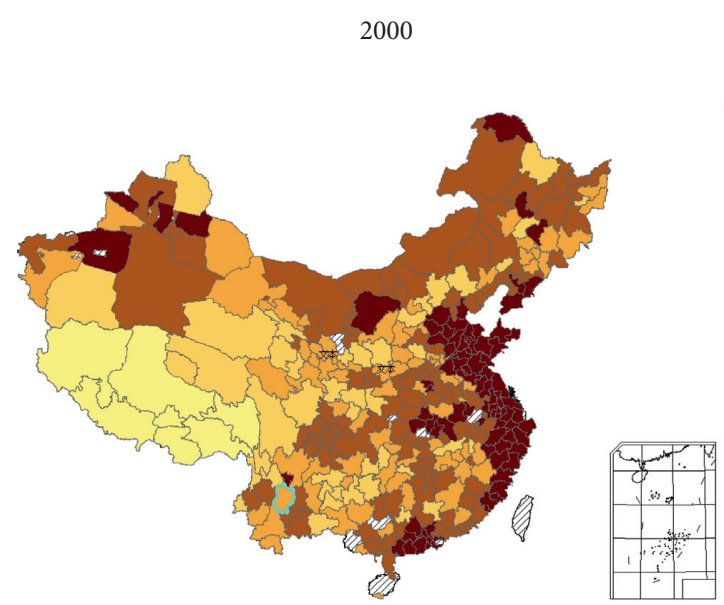

$\mathrm{N}$

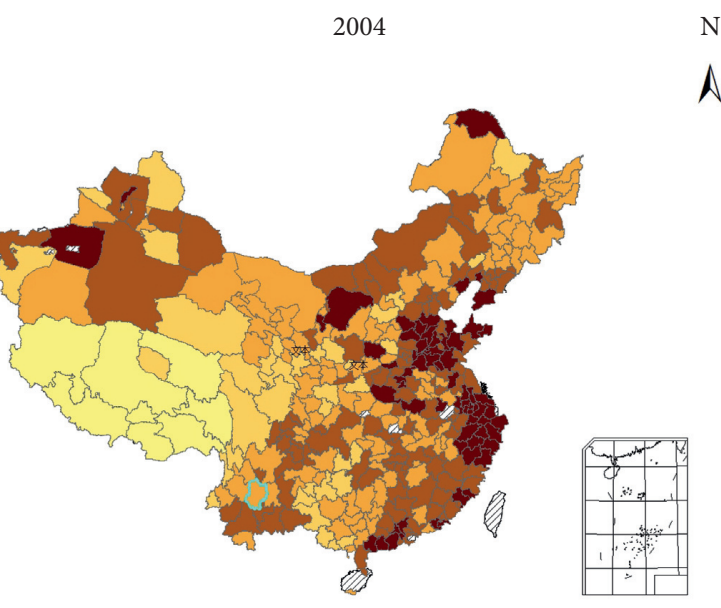

$\mathrm{N}$

TFP

TFP

Tfp_op2000

Tfp_op2004

$\square 0.010000$
$\square 0.010001-1.860245$
$\square$
$1.860246-2.361051$
$2.361052-2.793560$
$2.793561-3.729732$
$\square$ null
$\square$ the South China Sea

$\square 0.020000-0.999074$

$\square 0.999075-2.273889$

$\square 2.273890-2.679856$

$2.679857-2.987781$

$2.987782-3.572651$

UIII null

— the South China Sea

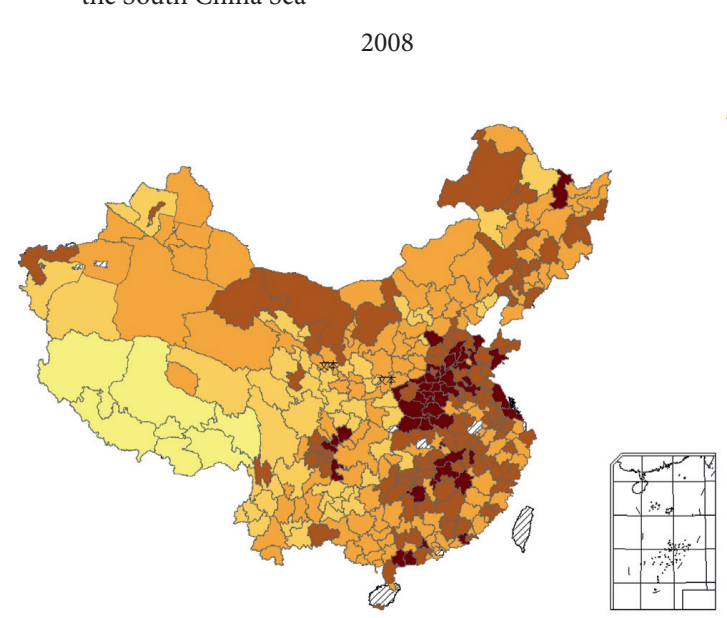

A

A

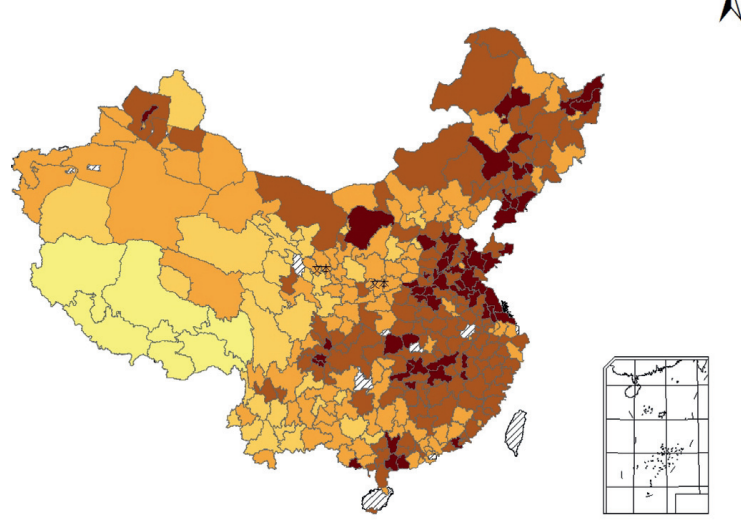

TFP

TFP

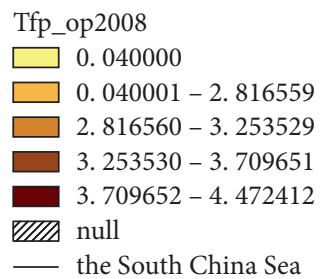

Tfp_op2013

$\square 0.070000$

$\square 0.070001-2.866759$

$\square 2.866760-3.343162$

ए $3.343163-3.779970$

$3.779971-4.846473$

पIIA null

— the South China Sea

FIGURE 3: Firm productivity weighted average, by region, in 2000, 2004, 2008, and 2013.

Krugman [44] derives the market potential from general equilibrium. The expression formula used in Krugman's [44] study is $\mathrm{MP}_{i}=\sum_{j=1}^{R} \tau_{i j}^{1-\sigma} \times E_{j} / G_{j}^{1-\sigma}$, where $M P_{i}$ is the market potential of the place of origin $i, \tau_{i j}^{1-\sigma}$ is the transportation cost between city $i$ and city $j, \sigma$ is the product elasticity of substitution, $E_{j}$ is the consumption expense of city $j$, and $G_{j}$ is the price index of city $j$. In contrast with Harris's [43] analysis of market potential, Euclidean distance is replaced by the transaction cost between two cities; this cost depends not only on geographical distance but also on degree of openness to trade, trade barriers, and other factors. The size of the target market is replaced by the demand, which depends on market demand capacity, as well as the number and price of competitive firms. From this perspective, 
market potential as described by Harris [43] can be seen as a special case of Krugman's [44] market potential. In practical applications, Krugman's [44] analysis of market potential also faces challenges, however. For one thing, it is difficult to obtain data for many of the variables.

Donaldson [8] proposed the concept of "market access." Market access depends on the economic aggregate of the target market, on the one hand, and the transportation cost between two places with parameter assumptions, on the other hand. Donaldson [8] uses the formula $\sum_{j=1}^{R} \tau_{i j}^{-\theta} \mathrm{GDP}_{j}$, where $\tau_{i j}$ refers to the transportation cost, including the transportation time and expenses. $\theta$ is the degree of influence on the local market. It can be seen that Donaldson's market access is a concept that lies somewhere between the contrasting accounts of market potential of Harris [43] and Krugman [44].

Chen et al. [45] summarized the method for calculating market potential indicators, offering a general expression of market potential via formula (4). Donaldson's [8] “market access" is a special case of this formula.

$$
\mathrm{MP}_{i}=\frac{\sum_{j=1}^{R} M_{j}}{f\left(\tau_{i j}\right)} .
$$

Here, $f\left(\tau_{i j}\right)$ is an impedance function that describes the resistance to the target market as the transportation cost increases, and the impedance function is determined by the traffic purpose, the traffic mode, the spatial scale of travel, the personal characteristics of the traveler, the area of the destination, and other factors [46]. In applying this formula, it is necessary to choose the function form and parameter values that match the actual situation. Usually, there are two forms of the impedance function $f\left(\tau_{i j}\right)$ :

$$
\begin{aligned}
& \mathrm{f}\left(\tau_{i j}\right)=\tau_{i j}{ }^{\theta}, \\
& f\left(\tau_{i j}\right)=\exp \left(\beta \times \tau_{i j}\right),
\end{aligned}
$$

where $\theta$ and $\beta$ are parameters to be estimated in the function.

In order to calculate the market potential indicator, we should first choose the appropriate impedance function. Geurs and Ritsema van Eck [47] found that the form $f\left(\tau_{i j}\right)=$ $\tau_{i j}^{\theta}$ decays too fast in short-distance transport, while the form $f\left(\tau_{i j}\right)=\exp \left(\beta \times \tau_{i j}\right)$ is more suitable. Therefore, the formula we use for calculating market potential is as follows:

$$
M P_{i}=\frac{\sum_{j=1}^{R} M_{j}}{\exp \left(\beta \times \tau_{i j}\right)} .
$$

In this formula, $M_{j}$ is size of the target market, city $j$, which is indicated by GDP of the city. $\tau_{i j}$ is the transportation cost between the two cities. In accordance with the method used by Baum-Snow et al. [2], $\tau_{i j}$ is the multiple of the transportation cost converted on the basis of the shortest travel time, which is greater than 1 . The calculation formula is as follows:

$$
\tau_{i j}=1+0.004 \rho\left(\text { traveltime }_{i j}\right)^{0.8} .
$$

This formula can simultaneously capture economic cost and time cost. traveltime $e_{i j}$ is the shortest travel time (in hours) on the highway between the origin city $i$ and the target city $j . \rho$ is the freight conversion factor of the shortest travel time in 8 hours of the transit day. Hummels and Schaur [48] estimated that this cost is equivalent to an ad valorem duty of about $0.6 \%$ to $2.1 \%$ per day. Limao and Venables [49] estimate that the freight cost for each ton per 1000 miles is $2 \%$ of the cost of goods, or $1 \%$ every day. When $\rho=1$, according to formula (8), the daily transportation cost of an 8 -hour transit is $2.1 \%$. Therefore, in accordance with Baum-Snow et al. [2]; we assume $\rho=1$ in this paper.

To measure market potential in relation to highways, it is necessary to further estimate the parameter $\beta$ after obtaining the shortest travel time for the highways.

In estimating parameter $\beta, \mathrm{Yi}$ and $\mathrm{Kim}$ [50] used the impedance function of formula (6), adopted the inter-city traffic and transportation costs in Korea, and estimated that the parameter value is about 0.017. Rosik et al. [46] arrived at a threshold value of 0.009 to 0.049 in their research on the region of one country. Since the annual passenger flow volume is different from year to year, however, the value of the parameter should change with time. In this paper, we improve on Yi and Kim [50]'s practice of setting $\beta$ as a fixed value, estimating parameter $\beta$ year by year.

Due to the lack of regional vector data for passenger flow in China, we first transformed the passenger capacity of each city into vector data according to the population of each city and the distance between two cities, generated an OD matrix, and then calculated the gravity coefficient between city $i$ and city $j$ according to formula (9):

$$
k_{i j}=\frac{\sqrt{M_{i}} * \sqrt{M_{j}}}{d_{i j}},
$$

where $k_{i j}$ is the coefficient of gravitation between the city $i$ and city $j$ based on the population and space distance. $M_{i}$ and $M_{j}$ are, respectively, the population of the city $i$ and city $j . d_{i j}$ is the distance between the city $i$ and city $j$. For purposes of calculation, we used the straight-line distance between the government offices in two given cities.

According to formula (10), with the coefficient of gravitation as the weight, the passenger traffic of $i$ is equally weighted and distributed across each city:

$$
\begin{array}{r}
O D_{i j_{1}}=p c_{i} * \frac{k_{i j_{1}}}{k_{i j_{1}}+k_{i j_{2}}+k_{i j_{3}}+\ldots+k_{i j_{n}}}, \\
O D_{i j_{2}}=p c_{i} * \frac{k_{i j_{2}}}{k_{i j_{1}}+k_{i j_{2}}+k_{i j_{3}}+\ldots+k_{i j_{n}}}, \\
\vdots \\
O D_{i j_{n}}=p c_{i} * \frac{k_{i j_{n}}}{k_{i j_{1}}+k_{i j_{2}}+k_{i j_{3}}+\ldots+k_{i j_{n}}} .
\end{array}
$$

In this formula, $O D_{i j_{n}}$ is the passenger capacity between the city $i$ and the city $j_{n} \cdot p c_{i}$ is the passenger capacity of the city $i . k_{i j_{n}}$ is the coefficient of gravitation between the city $i$ and city $j_{n}$. 
The indicator $\beta$ is estimated according to

$$
\ln O D_{i j}=\alpha_{i} \ln M_{i}+\alpha_{j} \ln M_{j}-\beta T_{i j},
$$

where $\mathrm{OD}_{\mathrm{ij}}$ is the passenger capacity between the city $i$ and $j$. $O D_{i j}=M_{i}^{\alpha_{i}} M_{j}^{\alpha_{j}} \exp \left(T_{i j}\right)^{-\beta}$, with $T_{i j}$ being the shortest highway travel time between city $i$ and $j$.

Using the data on transportation and passenger capacity in the City Statistics Yearbook, we estimate $\beta$ for the period 2000-2013 year by year. The result is shown in Table 2. It can be seen that the coefficient increases over time.

Finally, we use formula (7) to calculate the market potential of cities. Table 3 is the average value of the log market potential of various prefecture-level cities each year.

As was the case with travel time, market potential also shows a center-periphery distribution pattern. The market potential of the Beijing-Tianjin-Hebei region, the Yangtze River Delta region, and the middle reaches of the Yangtze River is greatest, and then gradually decreases toward the periphery (Figure 4).

\subsection{Control Variable}

Enterprise age (age): According to the theory of enterprise life cycle, the development of an enterprise should go through three stages of growth, maturity, and decline. In the growth stage, due to "learning by doing" and innovation, productivity gradually increases, while after reaching maturity, "lockstep" causes productivity to fall. We take the current year minus the year the enterprise first appeared in the database as the enterprise age.

Asset size (size): With the continuous expansion of the enterprise scale, the specialization ability increases, which creates favorable conditions for the division of labor, reduces the production cost, and improves the production efficiency [51]. We select the asset size as the proxy variable of the enterprise scale.

State-owned capital ratio (state-owned): Due to institutional reasons, the productivity of state-owned enterprises is relatively low, while private enterprises formed under the market mechanism have better technical characteristics and higher productivity. We choose the proportion of state-owned capital as the proxy variable of institutional factors.

Regional R\&D capital (R\&D): The increase in research and development investment is an important engine of productivity growth [52]. We select regional R\&D capital to measure R\&D inputs.

Population density (popdens): Compared to smaller cities, in large cities with large population density and dense economic activities, the production efficiency of enterprises is higher [53]. However, too high population density will produce crowding effect, which is not conducive for the improvement of productivity. We predict an inverted U-shaped relationship between population density and productivity, and introduce population density and its square term into the model.
TABLE 2: Estimating parameter $\beta$ using the impedance function.

\begin{tabular}{cccc}
\hline Year & Estimated value of $\beta$ & Year & Estimated value of $\beta$ \\
\hline 2000 & 0.014 & 2007 & 0.014 \\
2001 & 0.012 & 2008 & 0.013 \\
2002 & 0.012 & 2009 & 0.014 \\
2003 & 0.014 & 2010 & 0.029 \\
2004 & 0.013 & 2011 & 0.033 \\
2005 & 0.015 & 2012 & 0.044 \\
2006 & 0.014 & 2013 & 0.044 \\
\hline
\end{tabular}

TABLE 3: Log market potential value of cities in China, 2000-2013.

\begin{tabular}{cccc}
\hline Year & Log market potential & Year & Market potential \\
\hline 2000 & 11.2629 & 2007 & 12.3715 \\
2001 & 11.3689 & 2008 & 12.5623 \\
2002 & 11.4891 & 2009 & 12.8385 \\
2003 & 11.6621 & 2010 & 12.8551 \\
2004 & 11.8549 & 2011 & 13.0384 \\
2005 & 12.0238 & 2012 & 13.1474 \\
2006 & 12.1865 & 2013 & 13.2434 \\
\hline
\end{tabular}

Foreign direct investment (FDI): FDI can improve the enterprises' productivity by imitating and learning the technology and management experience of foreign enterprises to improve market competition [54, 55]. We take regional foreign direct investment as the measure of FDI.

The enterprise-level data in the control variables comes from China's industrial enterprise database, the regionallevel data mainly comes from the China City Statistical Yearbook, and some missing years are supplemented by China Regional Statistical Yearbook. In order to ensure the integrity of the sample, we supplement the data for autonomous prefectures and leagues with the Provincial Statistical Yearbook and Statistical Bulletin. A statistical description of the main variables is presented as Table 4 .

\section{Empirical Specification}

In order to explore the impact of highway development on total factor productivity, in Section 5, we first use the method of Lin [56] to construct the following baseline empirical model:

$$
\begin{aligned}
\ln \left(\mathrm{TFP}_{i c t}\right)= & \alpha+\beta_{1} \text { Traveltime }_{c t}+\beta_{2} V_{i t}+\beta_{3} \mathrm{O}_{c t}+\beta_{4} T_{c t} \\
& +\delta_{t}+\delta_{i}+\varepsilon_{i c t} .
\end{aligned}
$$

$\ln \left(\mathrm{TFP}_{i c t}\right)$ is the explained variable, namely, the total factor productivity of city $c$ in year $t$, which is the sum of the shortest travel time from the city to all other cities. TFP ict indicates the total factor productivity of the enterprise $i$ located in city $c$ in the $t$ year. Traveltime $c$ is the main explanatory variable, namely, the shortest travel time of the highway. $\beta_{1}$ is the estimation coefficient. If $\beta_{1}<0$, this indicates that the reduction of travel time brought about by highways has significantly increased the total factor productivity of enterprises, that is, the highway positively affects 


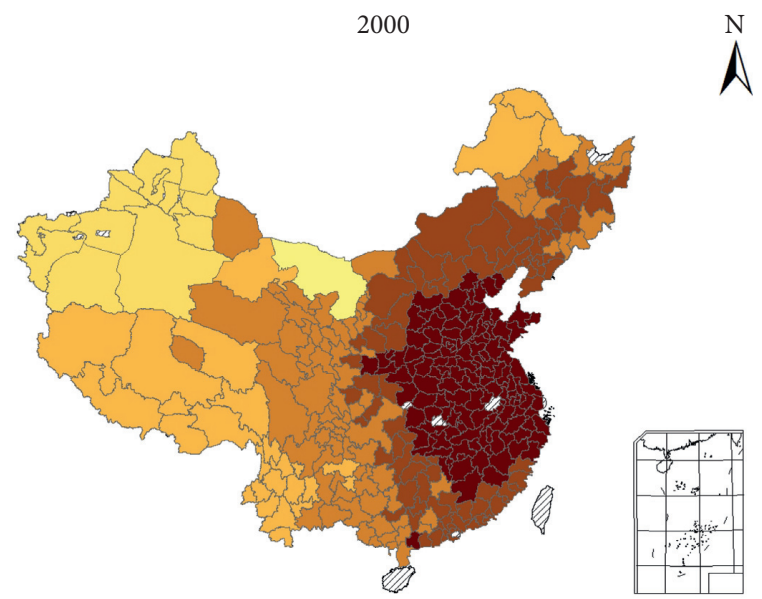

$\stackrel{N}{N}$

2004

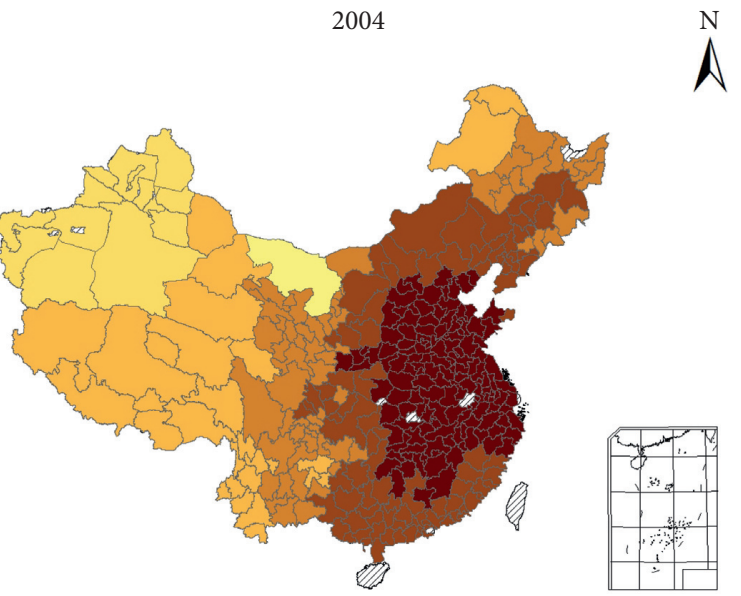

$\stackrel{N}{\Lambda}$

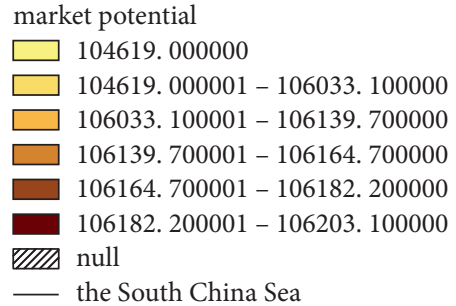

_ the South China Sea

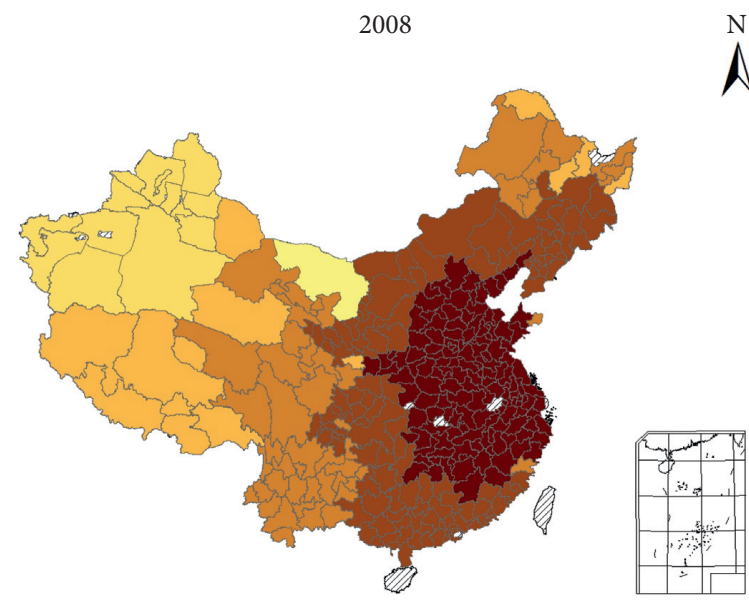

market potential

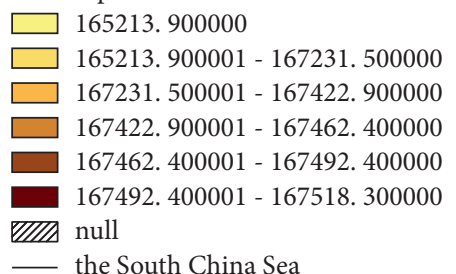

2013

(1)

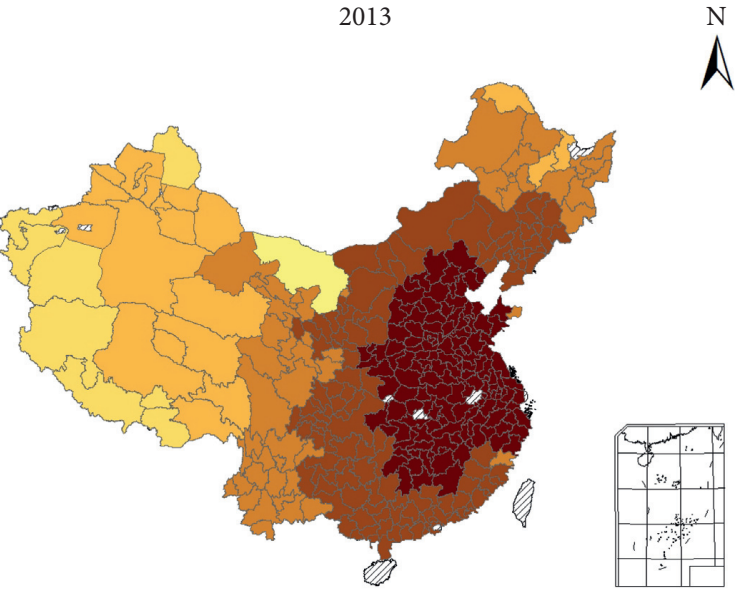

market potential

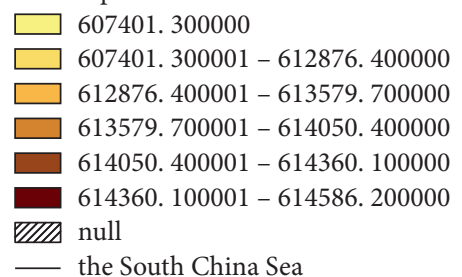

Figure 4: Market potential across the different regions China in 2000, 2004, 2007, and 2013.

enterprise productivity. Conversely, if $\beta_{1}>0$, this means that the highway has a negative impact on productivity.

$V_{i t}$ is a control variable at the firm level, including the age of the enterprise (Age), the size of the assets (Scale), the strength of the export (Export), and the proportion of stateowned capital (Own State), which is used to control the impact of the company's own factors on productivity.
$\mathrm{O}_{c t}$ is a control variable at the city level, including Gross Domestic Product (GDP), Population (POP), Foreign Direct Investment (FDI), Research and Development capital (R\&D), which is used to control the impact of regional characteristics on local productivity.

$T_{c t}$ is a control variable for other transportation; we select the length of ordinary rail (Railway), which is used to 
TABLe 4: Statistical description of the main variables.

\begin{tabular}{lccc}
\hline Name & Description & Mean & Standard deviation \\
\hline TFP & Log of enterprise total factor productivity & 3.2084 & 1.1014 \\
Traveltime & Log of travel time to various cities & 8.9189 & 12.3972 \\
MP & Log of market potential & 1.9973 & 0.2715 \\
Age & Log of enterprise age & 9.8982 & 0.6102 \\
Scale & Log of total enterprise assets & 0.1498 & 0.7960 \\
Export & Ratio of export delivery value to gross industrial output & 0.0468 & 1.5983 \\
Own state & Ratio of state-owned capital to the total assets of the enterprise & 7.4207 & 0.3358 \\
GDP & Log of GDP & 11.89178 & 0.2004 \\
R\&D & Log of city R\&D capital & 8.1434 & 1.1388 \\
POP & Log of population & 12.9379 & 1.8344 \\
FDI & Log of direct foreign investment & 5.3951 & 1.9006 \\
Railway & Log of ordinary railway mileage & 0.9881 \\
\hline
\end{tabular}

control the impact of other means of transportation on productivity. $\delta_{t}$ is time fixed effect to control the macroeconomic impact in the time dimension. $\delta_{i}$ is firm fixed effect that controls individual characteristics that do not change over time.

To better capture the impact of highway on enterprise productivity, in the sixth section, we use the market potential approach and examine the impacts of market potential growth, induced by highway, on enterprise productivity. Compared with the existing research methods of quantifying transportation infrastructure, there are three major advantages of market potential: first, it quantitatively evaluates the comprehensive impact of transportation infrastructure. With the expansion of transportation infrastructure, the transport cost between cities is significantly reduced. The more convenient the transportation, the higher the market potential. Second, it depicts the overall impact of transportation infrastructure on each city. In the process of calculation, all possible transportation schemes in the global scope are used, that is, the degree of global convenience within the national transportation network and the degree of interconnection with important economic regions are used to determine the market potential. Third, it can describe both the direct and indirect impact of transportation infrastructure construction. When the transportation facilities of neighboring cities become more perfect, even if the conditions of the city do not change, it will have a significant impact on the results and improve its market potential.

According to the analysis above, the model is:

$$
\ln \left(\mathrm{TFP}_{i c t}\right)=\alpha+\beta_{1} \mathrm{MP}_{c t}+\beta_{2} V_{i t}+\beta_{3} \mathrm{O}_{c t}+\beta_{4} T_{c t}+\delta_{t}+\delta_{i}+\varepsilon_{i c t} \text {, }
$$

where $\mathrm{MP}_{c t}$ is the market potential induced by highway of city $c$ in year $t . \beta_{1}$ is the estimation coefficient, $\beta_{1}>0$ indicates that the enhanced market potential induced by highway construction has significantly increased the total factor productivity of enterprises.

\section{Travel Time and Productivity}

For a preliminary visualization of the relationship between the travel time for highways and firm productivity, see the generated scatter diagram and fit line in Figure 5. It is evident that the travel time for highways is negatively correlated with firm productivity, a finding that is in line with our expectations.

5.1. Baseline Regression. Table 5 reports the results of the two-way fixed-effect model that we used in our study. Model (1) introduces the main explanatory variables, and examines the independent impact of highway construction on productivity. Models (2) and model (3) gradually introduce control variables at the firm level and region level. The regression result shows that the coefficient of the shortest highway travel time (Traveltime) on firm productivity is always significantly negative, so the reduction of travel time brought about by highway construction significantly and positively affects firm productivity. On average, the construction of highways has reduced the travel time between cities, which in turn increases firm productivity in cities.

5.2. Robustness Test. We conducted a robustness test of the benchmark regression results, targeting the following four issues:

(1) Referring to the method of Liu et al. [57], Zhang [6], and so on, we selected highway mileage, highway density, and highway mileage per capita to replace the travel time as the proxy variable for the main explanatory variable. Tables 6 and 7 describe highway density in China in 2000 and 2013.The regression results are shown in model (1), model (2), and model (3) in Table 8.

(2) In order to avoid the influence of measurement error on the results, we used the Levinsohn-Petrin method (LP method) to recalculate the firm total factor productivity, instead of using the OP method as the proxy variable for the explanatory variable. The results are shown in the model (4) of Table 8.

(3) Considering the data-quality problems in the Chinese industrial enterprise database, we selected the time period 2000-2008 since there are relatively good-quality data for this period for the purposes of regression. The results are shown in model (5) of Table 8. 


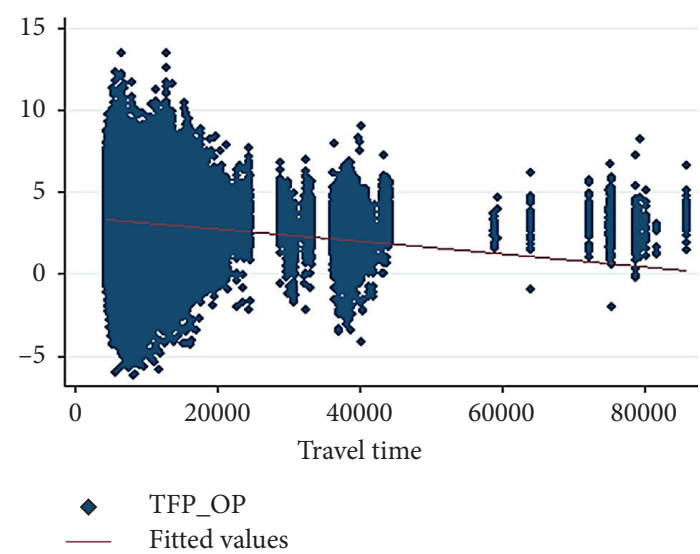

FIGURe 5: Highway travel time and firm productivity, 2000-2013.

TABLE 5: Result of baseline regressions.

\begin{tabular}{|c|c|c|c|}
\hline & $\begin{array}{l}(1) \\
\text { TFP }\end{array}$ & $\begin{array}{l}(2) \\
\text { TFP }\end{array}$ & $\begin{array}{l}(3) \\
\text { TFP }\end{array}$ \\
\hline Traveltime & $\begin{array}{c}-0.3014^{* * *} \\
(-15.6027)\end{array}$ & $\begin{array}{c}-0.3344^{* * *} \\
(-17.9077)\end{array}$ & $\begin{array}{l}-0.2018^{* * *} \\
(-10.7397)\end{array}$ \\
\hline Age & & $\begin{array}{l}0.0654^{* * *} \\
(36.8537)\end{array}$ & $\begin{array}{l}0.0653^{* * *} \\
(36.9506)\end{array}$ \\
\hline Scale & & $\begin{array}{l}0.2278^{* * *} \\
(168.9943)\end{array}$ & $\begin{array}{c}0.2264^{* * *} \\
(167.7992)\end{array}$ \\
\hline Export & & $\begin{array}{c}0.0101^{* * *} \\
(3.9584)\end{array}$ & $\begin{array}{c}0.0095^{* * *} \\
(3.7152)\end{array}$ \\
\hline Own state & & $\begin{array}{c}-0.1034^{* * *} \\
(-15.3840)\end{array}$ & $\begin{array}{c}-0.0985^{* * *} \\
(-14.6627)\end{array}$ \\
\hline GDP & & & $\begin{array}{l}0.1921^{* * * *} \\
(28.3932)\end{array}$ \\
\hline $\mathrm{R} \& \mathrm{D}$ & & & $\begin{array}{c}0.0223^{* * *} \\
(16.4775)\end{array}$ \\
\hline POP & & & $\begin{array}{c}0.0085^{* * *} \\
(8.3017)\end{array}$ \\
\hline FDI & & & $\begin{array}{l}0.0216^{* * * *} \\
(17.9286)\end{array}$ \\
\hline Railway & & & $\begin{array}{l}-0.0538^{* * *} \\
(-10.5808)\end{array}$ \\
\hline Constant & $\begin{array}{l}5.8450^{* * * *} \\
(32.4057)\end{array}$ & $\begin{array}{l}3.9560^{* * *} \\
(22.6839)\end{array}$ & $\begin{array}{c}1.2244^{* * *} \\
(6.4738)\end{array}$ \\
\hline Firm fixed effect & Yes & Yes & Yes \\
\hline Time fixed effect & Yes & Yes & Yes \\
\hline$N$ & $3,027,046$ & $3,027,046$ & $3,027,046$ \\
\hline$R$-squared & 0.0470 & 0.0914 & 0.0932 \\
\hline
\end{tabular}

Note. Standard errors are stated in parentheses below point estimates. *** $1 \%, * * 5 \%$, and ${ }^{*} 10 \%$ significance levels.

(4) Due to data-quality problems in the industrial enterprise database for 2010, we independently eliminated the data for 2010 for purposes of regression. The results are shown in the model (6) of Table 8.

The coefficient of highway mileage (Highway_mileage) in model (1), highway density (Highway_density) in model (2), and highway mileage per capita (Highway_per) in model (3) is significantly positive, and the coefficients of travel time in model (4), model (5), and model (6) are all significantly negative. All regression results prove that these results are robust.
TABle 6: Highway density in different regions of China.

\begin{tabular}{lcccc}
\hline Year & East & Middle & West & Northeast \\
\hline 2000 & 86.51 & 28.45 & 5.34 & 21.65 \\
2013 & 415.68 & 341.60 & 74.15 & 150.24 \\
\hline
\end{tabular}

TABLE 7: Highway mileage per capital in different regions of China.

\begin{tabular}{lcccc}
\hline Year & East & Middle & West & Northeast \\
\hline 2000 & 17.83 & 8.32 & 10.35 & 16.02 \\
2013 & 72.08 & 95.17 & 135.36 & 108.91 \\
\hline
\end{tabular}

5.3. Discussion of Endogeneity. Due to the reverse-causality problem between location conditions and regional economic development, the goal of China's "five vertical and seven horizontal" National Trunk Highway System (NTHS) is to connect all major provincial capitals and large cities with a population over 500,000. These cities have better economic conditions, larger population size, and bigger market scale, so the local enterprises enjoy greater productivity. A better way to solve endogeneity, however, is to use instrumental variables to conduct a two-stage regression. The selection of instrumental variables needs to meet two requirements: the first requirement is to have a significant connection with the endogenous explanatory variables, and the second requirement is that the instrumental variables must be exogenous [58]. Our study adopts the average elevation of each city as the instrumental variable. Elevation is an important factor affecting the construction of highways, and the difficulty, duration, and cost of highway construction in highelevation areas are obviously higher than in low-elevation areas, which indicates that there is a strong correlation between highway construction and local elevation. In addition, it seems that elevation cannot affect enterprise productivity through other ways, that is to say, it can only affect enterprise productivity through highway construction, that is, it can satisfy exogeneity.

Since the instrument of geographic information like elevation does not change over time, we refer to Lin et al. [35] to construct an interaction term between the average elevation and the dummy variables of each year to construct a tool variable combination. Table 9 reports the regression result of the instrumental variable. Model (1) is the result of the OLS method, model (2) is the result of the 2SLS method, and model (3) is the first-stage regression result. In model (3), elevation and time interaction items are significantly positive, that is, the elevation is positively correlated with the travel time, indicating that the elevation has a significant negative relationship with the highway construction, which is consistent with the intuition, and the instrumental variable is reasonable. Kleibergen-Paap rk Wald F statistics is 23.188, which is larger than the empirical value of 10 proposed by Staiger and Stock [59]. Therefore, the hypothesis of weak instrumental variables is rejected, indicating the validity of instrumental variables. The 2SLS regression result is consistent with the benchmark regression, indicating that after considering endogeneity, the reduction of travel time can still improve the firm's productivity. Nationally, then, the construction of highways has a significant positive effect on firm productivity. 
TABLE 8: Result of robustness check.

\begin{tabular}{|c|c|c|c|c|c|c|}
\hline & $\begin{array}{l}(1) \\
\text { TFP }\end{array}$ & $\begin{array}{l}(2) \\
\text { TFP }\end{array}$ & $\begin{array}{l}(3) \\
\text { TFP }\end{array}$ & $\begin{array}{c}(4) \\
\text { TFP_LP }\end{array}$ & $\begin{array}{l}(5) \\
\text { TFP }\end{array}$ & $\begin{array}{l}(6) \\
\text { TFP }\end{array}$ \\
\hline Highway_mileage & $\begin{array}{c}0.0110^{* * *} \\
(11.4146)\end{array}$ & & & & & \\
\hline Highway_density & & $\begin{array}{c}0.0154^{* * *} \\
(9.6431)\end{array}$ & & & & \\
\hline Highway_per & & & $\begin{array}{c}0.0142^{* * *} \\
(17.3571)\end{array}$ & & & \\
\hline Traveltime & & & & $\begin{array}{c}-0.1889^{* * *} \\
(-9.4952)\end{array}$ & $\begin{array}{c}-0.3673^{* * *} \\
(-15.5392)\end{array}$ & $\begin{array}{r}-0.2466^{* * *} \\
(-11.8179)\end{array}$ \\
\hline Age & $\begin{array}{l}0.0648^{* * *} \\
(36.7299)\end{array}$ & $\begin{array}{l}0.0648^{* * *} \\
(36.7055)\end{array}$ & $\begin{array}{l}0.0648^{* * *} \\
(36.7167)\end{array}$ & $\begin{array}{l}0.0631^{* * *} \\
(32.7159)\end{array}$ & $\begin{array}{l}0.0505^{* * *} \\
(25.6216)\end{array}$ & $\begin{array}{l}0.0705^{* * *} \\
(37.5753)\end{array}$ \\
\hline Scale & $\begin{array}{l}0.2261^{* * *} \\
(167.8115)\end{array}$ & $\begin{array}{c}0.2261^{* * *} \\
(167.8189)\end{array}$ & $\begin{array}{c}0.2260^{* * *} \\
(167.7204)\end{array}$ & $\begin{array}{c}0.2129^{* * *} \\
(154.6469)\end{array}$ & $\begin{array}{l}0.2481^{* * * *} \\
(143.1076)\end{array}$ & $\begin{array}{l}0.2584^{* * *} \\
(178.6563)\end{array}$ \\
\hline Export & $\begin{array}{c}0.0096^{* * *} \\
(3.7669)\end{array}$ & $\begin{array}{c}0.0096^{* * *} \\
(3.7863)\end{array}$ & $\begin{array}{c}0.0095^{* * *} \\
(3.7425)\end{array}$ & $\begin{array}{c}0.0021 \\
(0.7853)\end{array}$ & $\begin{array}{l}-0.0003 \\
(-0.0736)\end{array}$ & $\begin{array}{r}-0.0282^{* * *} \\
(-7.5324)\end{array}$ \\
\hline Own state & $\begin{array}{c}-0.0976^{* * *} \\
(-14.5739)\end{array}$ & $\begin{array}{l}-0.0983^{* * * *} \\
(-14.6778)\end{array}$ & $\begin{array}{l}-0.0965^{* * *} \\
(-14.4209)\end{array}$ & $\begin{array}{l}-0.1087^{* * *} \\
(-14.2069)\end{array}$ & $\begin{array}{l}-0.1155^{* * *} \\
(-15.6602)\end{array}$ & $\begin{array}{l}-0.1157^{* * *} \\
(-17.0196)\end{array}$ \\
\hline GDP & $\begin{array}{l}0.1996^{* * *} \\
(29.7123)\end{array}$ & $\begin{array}{l}0.1995^{* * *} \\
(29.7042)\end{array}$ & $\begin{array}{l}0.1992^{* * *} \\
(29.7118)\end{array}$ & $\begin{array}{l}0.2005^{* * *} \\
(26.6719)\end{array}$ & $\begin{array}{l}0.0763^{* * * *} \\
(11.0427)\end{array}$ & $\begin{array}{l}0.1813^{* * *} \\
(25.9467)\end{array}$ \\
\hline $\mathrm{R} \& \mathrm{D}$ & $\begin{array}{l}0.0209^{* * * *} \\
(15.4730)\end{array}$ & $\begin{array}{l}0.0210^{* * * *} \\
(15.5692)\end{array}$ & $\begin{array}{l}0.0207^{* * *} \\
(15.3359)\end{array}$ & $\begin{array}{l}0.0215^{* * *} \\
(15.3309)\end{array}$ & $\begin{array}{l}0.0220^{* * * *} \\
(11.1054)\end{array}$ & $\begin{array}{l}0.0284^{* * *} \\
(18.6328)\end{array}$ \\
\hline POP & $\begin{array}{c}0.0089^{* * * *} \\
(8.6940)\end{array}$ & $\begin{array}{c}0.0088^{* * *} \\
(8.5933)\end{array}$ & $\begin{array}{c}0.0088^{* * *} \\
(8.5869)\end{array}$ & $\begin{array}{l}0.0149^{* * *} \\
(14.2049)\end{array}$ & $\begin{array}{l}0.0338^{* * *} \\
(26.0262)\end{array}$ & $\begin{array}{l}0.0115^{* * *} \\
(10.2237)\end{array}$ \\
\hline FDI & $\begin{array}{c}0.0224^{* * *} \\
(18.6117)\end{array}$ & $\begin{array}{l}0.0226^{* * *} \\
(18.7423)\end{array}$ & $\begin{array}{l}0.0218^{* * *} \\
(18.0795)\end{array}$ & $\begin{array}{c}0.0202^{* * *} \\
(15.5531)\end{array}$ & $\begin{array}{l}0.0135^{* * *} \\
(10.0532)\end{array}$ & $\begin{array}{c}0.0221^{* * *} \\
(17.2650)\end{array}$ \\
\hline Railway & $\begin{array}{c}-0.0552^{* * *} \\
(-10.9455)\end{array}$ & $\begin{array}{c}-0.0556^{* * *} \\
(-11.0171)\end{array}$ & $\begin{array}{l}-0.0557^{* * *} \\
(-11.0705)\end{array}$ & $\begin{array}{c}-0.0464^{* * *} \\
(-9.1843)\end{array}$ & $\begin{array}{c}-0.0366^{* * *} \\
(-4.0071)\end{array}$ & $\begin{array}{l}-0.0614^{* * *} \\
(-10.3969)\end{array}$ \\
\hline Constant & $\begin{array}{c}-0.7429^{* * *} \\
(-13.7597)\end{array}$ & $\begin{array}{l}-0.7356^{* * *} \\
(-13.6280)\end{array}$ & $\begin{array}{l}-0.7467^{* * *} \\
(-13.8667)\end{array}$ & $\begin{array}{c}0.9622^{* * * *} \\
(4.7820)\end{array}$ & $\begin{array}{l}3.0707^{* * *} \\
(13.0519)\end{array}$ & $\begin{array}{c}1.3608^{* * *} \\
(6.5098)\end{array}$ \\
\hline Firm fixed effect & Yes & Yes & Yes & Yes & Yes & Yes \\
\hline Time fixed effect & Yes & Yes & Yes & Yes & Yes & Yes \\
\hline$N$ & $3,034,596$ & $3,034,596$ & $3,034,596$ & $3,027,046$ & $1,916,983$ & $2,811,883$ \\
\hline$R$-squared & 0.0930 & 0.0930 & 0.0932 & 0.0820 & 0.1015 & 0.0906 \\
\hline
\end{tabular}

Note. Standard errors are stated in parentheses below point estimates. ${ }^{* * *} 1 \%,{ }^{* *} 5 \%$, and ${ }^{*} 10 \%$ significance levels.

5.4. Time Trend of Highway Impact on Productivity. In order to further explore the dynamic changes of the influence of the highway on firm productivity, this paper introduces the interaction term between the year dummy variable and travel time into the benchmark regression equation. To prevent multicollinearity, the passage time and year 2000 are removed as a benchmark, and the interaction term in the regression result is basically significantly negative. We plot the absolute value of the influence coefficient of the travel time on productivity each year. The results are shown in Figure 6. From 2000 to 2013, the impact of highways on productivity has generally increased. From 2000 to 2004, the change of coefficient is relatively stable, while in the period from 2004 to 2008, it becomes relatively flat, and after 2008, the increasing trend of it is more obvious, indicating that the impact of the reduction of travel time on firm productivity has risen rapidly after 2008. From 2003 to 2007 is the stage of comprehensive construction of China's national trunk roads, the degree of networkization of the highway is improving, and the reduction of total travel time in the region is increasing, so that the firm productivity is raising due to the development of transportation infrastructure. Since there is a lag in the influence of transportation infrastructure, the impact becomes strong after 2008.

\section{Market Potential and Productivity}

6.1. Baseline Regression. To explore the mechanisms at work, we further examine the impact of highway-induced market potential on enterprise productivity. Table 10 reports the results. Model (1) introduces the market potential, model (2) and model (3) add control variables at the firm level and regional level, respectively, on the basis of model (1). It can be seen that the coefficient of market potential is significantly positive, indicating that the development of highway can promote firm productivity by improving market potential.

In order to make the conclusion more robust, we also use the method of Donaldson [8] to replace formula (8) to recalculate the market potential. The formula for calculating market potential by Donaldson [8] is

$$
\mathrm{MP}_{i}=\sum_{j=1}^{n} \frac{\mathrm{GDP}_{j}}{T_{i j}^{\theta}} .
$$

Here, $T_{i j}$ is the shortest travel time on the highway. The parameter $\theta$ is the trade elasticity describing the productivity distribution and is estimated using the EK 
TABle 9: Result of instrumental variable.

\begin{tabular}{|c|c|c|c|}
\hline Variables & $\begin{array}{l}\text { OLS } \\
\text { TFP }\end{array}$ & $\begin{array}{c}\text { Second stage } \\
\text { TFP }\end{array}$ & $\begin{array}{l}\text { First stage } \\
\text { Traveltime }\end{array}$ \\
\hline Traveltime & $\begin{array}{l}-0.2018^{* * *} \\
(-10.7397)\end{array}$ & $\begin{array}{l}-1.1570^{* * *} \\
(-88.1026)\end{array}$ & \\
\hline Traveltime_res & & $\begin{array}{l}0.6659^{* * *} \\
(48.2075)\end{array}$ & \\
\hline Elevation_2000 & & & $\begin{array}{c}0.0313^{* * *} \\
(104.7437)\end{array}$ \\
\hline Elevation_2001 & & & $\begin{array}{c}0.0334^{* * *} \\
(111.5930)\end{array}$ \\
\hline Elevation_2002 & & & $\begin{array}{l}0.0411^{* * *} \\
(146.2454)\end{array}$ \\
\hline Elevation_2003 & & & $\begin{array}{c}0.0372^{* * *} \\
(132.5134)\end{array}$ \\
\hline Elevation_2004 & & & $\begin{array}{l}0.0323^{* * *} \\
(146.5773)\end{array}$ \\
\hline Elevation_2005 & & & $\begin{array}{c}0.0319^{* * *} \\
(144.0628)\end{array}$ \\
\hline Elevation_2006 & & & $\begin{array}{l}0.0331^{* * *} \\
(161.1244)\end{array}$ \\
\hline Elevation_2007 & & & $\begin{array}{c}0.0329^{* * *} \\
(160.3346)\end{array}$ \\
\hline Elevation_2008 & & & $\begin{array}{c}0.0331^{* * *} \\
(142.6269)\end{array}$ \\
\hline Elevation_2009 & & & $\begin{array}{c}0.0336^{* * *} \\
(133.7109)\end{array}$ \\
\hline Elevation_2010 & & & $\begin{array}{c}0.0346^{* * *} \\
(182.0807)\end{array}$ \\
\hline Elevation_2011 & & & $\begin{array}{c}0.0315^{* * * *} \\
(163.6914)\end{array}$ \\
\hline Elevation_2012 & & & $\begin{array}{c}0.0335^{* * *} \\
(147.4631)\end{array}$ \\
\hline Elevation_2013 & & & $\begin{array}{c}0.0306^{* * *} \\
(173.6674)\end{array}$ \\
\hline Age & $\begin{array}{c}0.0653^{* * *} \\
(36.9506)\end{array}$ & $\begin{array}{l}-0.0576^{* * *} \\
(-71.3241)\end{array}$ & $\begin{array}{c}0.0019^{* * *} \\
(15.2815)\end{array}$ \\
\hline Scale & $\begin{array}{c}0.2264^{* * *} \\
(167.7992)\end{array}$ & $\begin{array}{l}0.2089^{* * *} \\
(481.1905)\end{array}$ & $\begin{array}{l}0.0023^{* * *} \\
(36.8894)\end{array}$ \\
\hline Export & $\begin{array}{c}0.0095^{* * *} \\
(3.7152)\end{array}$ & $\begin{array}{l}-0.0340^{* * *} \\
(-19.0374)\end{array}$ & $\begin{array}{c}0.0380^{* * *} \\
(172.9643)\end{array}$ \\
\hline Own state & $\begin{array}{l}-0.0985^{* * *} \\
(-14.6627)\end{array}$ & $\begin{array}{l}-0.6504^{* * *} \\
(-1.8 e+02)\end{array}$ & $\begin{array}{l}0.0228^{* * *} \\
(33.5935)\end{array}$ \\
\hline GDP & $\begin{array}{l}0.1921^{* * *} \\
(28.3932)\end{array}$ & $\begin{array}{l}0.0870^{* * *} \\
(55.2847)\end{array}$ & $\begin{array}{l}-0.0112^{* * *} \\
(-41.2738)\end{array}$ \\
\hline $\mathrm{R} \& \mathrm{D}$ & $\begin{array}{c}0.0223^{* * *} \\
(16.4775)\end{array}$ & $\begin{array}{l}-0.0221^{* * *} \\
(-39.4607)\end{array}$ & $\begin{array}{c}0.0116^{* * *} \\
(140.7426)\end{array}$ \\
\hline POP & $\begin{array}{c}0.0085^{* * *} \\
(8.3017)\end{array}$ & $\begin{array}{c}-0.0085^{* * *} \\
(-15.9969)\end{array}$ & $\begin{array}{l}0.0027^{* * *} \\
(31.0327)\end{array}$ \\
\hline FDI & $\begin{array}{l}0.0216^{* * *} \\
(17.9286)\end{array}$ & $\begin{array}{l}-0.0088^{* * *} \\
(-11.9593)\end{array}$ & $\begin{array}{r}-0.0034^{* * *} \\
(-18.1358)\end{array}$ \\
\hline Railway & $\begin{array}{c}-0.0538^{* * *} \\
(-10.5808)\end{array}$ & $\begin{array}{l}-0.0778^{* * *} \\
(-1.1 e+02)\end{array}$ & $\begin{array}{l}-0.0223^{* * *} \\
(-1.9 e+02)\end{array}$ \\
\hline Constant & $\begin{array}{c}1.2244^{* * *} \\
(6.4738)\end{array}$ & $\begin{array}{c}12.1491^{* * *} \\
(96.9508)\end{array}$ & $\begin{array}{c}9.2524^{* * * *} \\
(5.4 e+03)\end{array}$ \\
\hline $\begin{array}{l}\text { Firm fixed effect } \\
\text { Time fixed effect }\end{array}$ & $\begin{array}{l}\text { Yes } \\
\text { Yes }\end{array}$ & $\begin{array}{l}\text { Yes } \\
\text { Yes }\end{array}$ & $\begin{array}{l}\text { Yes } \\
\text { Yes }\end{array}$ \\
\hline $\begin{array}{l}\text { lime fixed effect } \\
N\end{array}$ & $\begin{array}{c}\text { Yes } \\
3,027,046\end{array}$ & $\begin{array}{l}\text { Yes } \\
3,027,046\end{array}$ & $\begin{array}{c}\text { Yes } \\
3,027,046\end{array}$ \\
\hline$R$-squared & 0.0932 & & 0.2970 \\
\hline Kleibergen-Paap rk Wald F & & & 23.188 \\
\hline
\end{tabular}

Note. Standard errors are stated in parentheses below point estimates. ${ }^{* * *} 1 \%$, ${ }^{* *} 5 \%$, and ${ }^{*} 10 \%$ significance levels. 


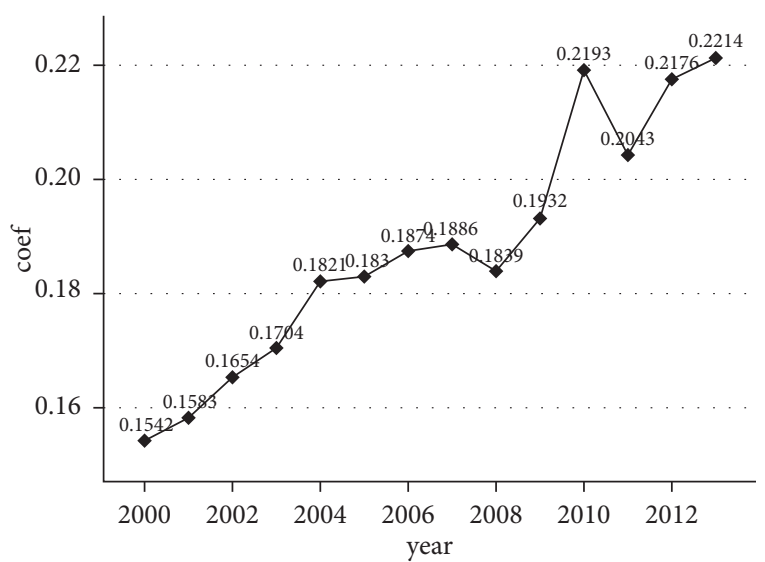

Figure 6: Time trend of highway impact on productivity.

TABLE 10: Result of mechanism test.

\begin{tabular}{|c|c|c|c|}
\hline Variables & $\begin{array}{l}(1) \\
\text { TFP }\end{array}$ & $\begin{array}{l}(2) \\
\text { TFP }\end{array}$ & $\begin{array}{l}(3) \\
\text { TFP }\end{array}$ \\
\hline MP & $\begin{array}{l}0.9050^{* * *} \\
(11.9135)\end{array}$ & $\begin{array}{l}1.6850^{* * *} \\
(21.4577)\end{array}$ & $\begin{array}{l}1.3868^{* * *} \\
(18.0265)\end{array}$ \\
\hline Age & & $\begin{array}{l}0.0652^{* * *} \\
(36.7873)\end{array}$ & $\begin{array}{l}0.0653^{* * *} \\
(36.9519)\end{array}$ \\
\hline Scale & & $\begin{array}{l}0.2289^{* * *} \\
(169.3974)\end{array}$ & $\begin{array}{l}0.2272^{* * *} \\
(168.0588)\end{array}$ \\
\hline Export & & $\begin{array}{c}0.0088^{* * *} \\
(3.4622)\end{array}$ & $\begin{array}{c}0.0085^{* * *} \\
(3.3351)\end{array}$ \\
\hline Own state & & $\begin{array}{c}-0.1018^{* * *} \\
(-15.1585)\end{array}$ & $\begin{array}{c}-0.0969^{* * *} \\
(-14.4403)\end{array}$ \\
\hline GDP & & & $\begin{array}{l}0.1864^{* * *} \\
(27.5666)\end{array}$ \\
\hline $\mathrm{R} \& \mathrm{D}$ & & & $\begin{array}{l}0.0230^{* * *} \\
(16.9750)\end{array}$ \\
\hline POP & & & $\begin{array}{c}0.0095^{* * *} \\
(9.2769)\end{array}$ \\
\hline FDI & & & $\begin{array}{l}0.0212^{* * *} \\
(17.5878)\end{array}$ \\
\hline Railway & & & $\begin{array}{l}-0.0535^{* * *} \\
(-10.4990)\end{array}$ \\
\hline Constant & $\begin{array}{c}-7.2086^{* * *} \\
(-8.3872)\end{array}$ & $\begin{array}{c}-18.2402^{* * *} \\
(-20.4995)\end{array}$ & $\begin{array}{c}-16.3346^{* * *} \\
(-18.7874)\end{array}$ \\
\hline Firm fixed effect & Yes & Yes & Yes \\
\hline Time fixed effect & Yes & Yes & Yes \\
\hline$N$ & $3,027,046$ & $3,027,046$ & $3,027,046$ \\
\hline$R$-squared & 0.0469 & 0.0916 & 0.0934 \\
\hline
\end{tabular}

Note. Standard errors are stated in parentheses below point estimates. *** $1 \%,{ }^{* *} 5 \%$, and ${ }^{*} 10 \%$ significance levels.

method [60]. Due to the availability of data, there is little literature on estimating $\theta$ between regions of a country. Bernard et al. [61] estimate the trade elasticity of the United States and consider $\theta$ to be 3.6. Donaldson [8] uses the inter-regional trade data from India to estimate $\theta$ to be approximately 3.6 , too. So in this paper, we take $\theta$ to be 3.6. Substitute formula (14) for the market potential calculated by formula (6) and re-regress it, the results are shown in Table 11. It can be seen from Table 11 that there is no qualitative change in the empirical results, and the regression results are still robust.
TABLE 11: Robust check of market potential approach.

\begin{tabular}{|c|c|c|c|}
\hline Variables & $\begin{array}{l}(1) \\
\text { TFP }\end{array}$ & $\begin{array}{l}(2) \\
\text { TFP }\end{array}$ & $\begin{array}{l}\text { (3) } \\
\text { TFP }\end{array}$ \\
\hline MP_theta & $\begin{array}{l}0.8423^{* * *} \\
(11.4612)\end{array}$ & $\begin{array}{l}1.6341^{* * *} \\
(21.5589)\end{array}$ & $\begin{array}{l}1.3530^{* * *} \\
(18.1847)\end{array}$ \\
\hline Age & & $\begin{array}{l}0.0654^{* * * *} \\
(36.8977)\end{array}$ & $\begin{array}{l}0.0655^{* * *} \\
(37.0405)\end{array}$ \\
\hline Scale & & $\begin{array}{l}0.2290^{* * *} \\
(169.3937)\end{array}$ & $\begin{array}{l}0.2273^{* * *} \\
(168.0534)\end{array}$ \\
\hline Export & & $\begin{array}{c}0.0088^{* * *} \\
(3.4553)\end{array}$ & $\begin{array}{c}0.0085^{* * *} \\
(3.3286)\end{array}$ \\
\hline Own state & & $\begin{array}{l}-0.1011^{* * *} \\
(-15.0437)\end{array}$ & $\begin{array}{c}-0.0963^{* * *} \\
(-14.3445)\end{array}$ \\
\hline GDP & & & $\begin{array}{l}0.1866^{* * *} \\
(27.6095)\end{array}$ \\
\hline $\mathrm{R} \& \mathrm{D}$ & & & $\begin{array}{l}0.0232^{* * *} \\
(17.0688)\end{array}$ \\
\hline POP & & & $\begin{array}{c}0.0094^{* * *} \\
(9.2135)\end{array}$ \\
\hline FDI & & & $\begin{array}{l}0.0211^{* * * *} \\
(17.4596)\end{array}$ \\
\hline Railway & & & $\begin{array}{c}-0.0536^{* * *} \\
(-10.5306)\end{array}$ \\
\hline Constant & $\begin{array}{c}-6.5007^{* * *} \\
(-7.8165)\end{array}$ & $\begin{array}{c}-17.6670^{* * * *} \\
(-20.5650)\end{array}$ & $\begin{array}{c}-15.9537^{* * *} \\
(-18.9640)\end{array}$ \\
\hline Firm fixed effect & Yes & Yes & Yes \\
\hline Time fixed effect & Yes & Yes & Yes \\
\hline$N$ & $3,027,046$ & $3,027,046$ & $3,027,046$ \\
\hline$R$-squared & 0.0469 & 0.0916 & 0.0934 \\
\hline
\end{tabular}

Note. Standard errors are stated in parentheses below point estimates. ${ }^{* * *} 1 \%,{ }^{* *} 5 \%$, and ${ }^{*} 10 \%$ significance levels.

6.2. Industry Sensitivity Analysis. Furthermore, we conduct industry sensitivity analysis, subdividing the sample according to the two-digit industry code to explore the impact of market potential induced by highways on firm productivity in different manufacturing industries. Table 12 lists all the regression coefficients and significance. In the industry regression results, the boost effect of the construction of highway on productivity is significant, especially for the industry of furniture manufacturing, special equipment manufacturing, leather, fur, feather (velvet) and its products, ferrous metal smelting and rolling industry, electrical machinery and equipment manufacturing industries. The products or inputs of these industries are relatively high in weight and large in volume, so the corresponding transportation costs and the requirements for transportation conditions are also high. Therefore, the development of the highway has a more significant and stronger effect on the productivity of industries highly dependent on transportation costs.

6.3. Regional Heterogeneity Analysis-Urban Centrality. In order to further explore the impact of highway construction on different regions of China, we conducted a sample regression for all prefecture-level cities in China according to the degree of centrality of the city. The concept of centrality was firstly proposed by Christaller [62]. Urban centrality refers to the relative importance of a city serving its outer regions and is an important breakthrough point for 
TABLE 12: Coefficient of all industry regression results.

\begin{tabular}{|c|c|c|}
\hline Industry code & Industry name & Coefficient \\
\hline 13 & Agricultural and sideline food processing & $0.4106^{*}$ \\
\hline 14 & Food manufacturing & 0.2994 \\
\hline 15 & Beverage manufacturing & $1.9326^{* * *}$ \\
\hline 16 & Tobacco & 0.6733 \\
\hline 17 & Textile & $2.8247^{* * *}$ \\
\hline 18 & Textile and garment, shoes, and hat manufacturing & 0.1150 \\
\hline 19 & Leather, fur, feather (velvet), and its products & $4.6027^{* * *}$ \\
\hline 20 & Wood processing and wood, bamboo, rattan, palm, grass products & $1.2559^{* * *}$ \\
\hline 21 & Furniture manufacturing & $3.7328^{* * *}$ \\
\hline 22 & Paper and paper products & $1.1905^{* * *}$ \\
\hline 23 & Copying of the printing industry and recording media & $0.7557^{* *}$ \\
\hline 24 & Culture and education, sporting goods manufacturing & $3.5383^{* * *}$ \\
\hline 25 & Petroleum processing, coking, and nuclear fuel processing industry & 0.1794 \\
\hline 26 & Chemical raw materials and chemical products manufacturing & 0.2868 \\
\hline 27 & Pharmaceutical manufacturing & $-2.8564^{* * *}$ \\
\hline 28 & Chemical fiber manufacturing & 0.9784 \\
\hline 29 & Rubber products & $2.3790^{* * *}$ \\
\hline 30 & Plastic products & $2.3786^{* * *}$ \\
\hline 31 & Nonmetallic mineral products & $0.9840^{* * *}$ \\
\hline 32 & Ferrous metal smelting and rolling processing & $1.8364^{* * *}$ \\
\hline 33 & Nonferrous metal smelting and rolling processing & $1.2547^{* *}$ \\
\hline 34 & Metal products & $2.1132^{* * *}$ \\
\hline 35 & General equipment manufacturing & $2.3235^{* * *}$ \\
\hline 36 & Special equipment manufacturing & $3.0903^{* * *}$ \\
\hline 37 & Transportation equipment manufacturing & $2.5552^{* * *}$ \\
\hline 39 & Electrical machinery and equipment manufacturing & $1.8231^{* * *}$ \\
\hline 40 & Communication equipment, computers, and other electronic equipment manufacturing & $2.1443^{* * *}$ \\
\hline 41 & Instrumentation and culture, office machinery manufacturing & 0.4827 \\
\hline 42 & Crafts and other manufacturing & $1.8220^{* *}$ \\
\hline 43 & Plastic products industry & $2.0349^{* *}$ \\
\hline
\end{tabular}

understanding the structure and evolution of urban networks $[63,64]$. Meyer [65] argues that regional economic linkage is an important driving force for the evolution of the US urban system. He suggests that the dynamic model of the urban system should be highly simplified in analyzing a spatial economy of this sort, so that the key processes involved can be grasped. This approach indicates that, although it is feasible to add some variables to one's analysis of centrality without changing the basic arguments, considering too many factors can cause confusion and misunderstanding. For this paper, we used the urban space gravity model to measure and calculate the economic linkage between cities. If a city has more economic links with other regions than does another city, its centrality in the urban network will be stronger. Urban space gravity depends on the distance between cities and the size and quality of each urban area. The urban spatial gravity model used in this paper is as follows:

$$
C_{i}=\sum_{j} \frac{\sqrt{P_{i}} * \sqrt{P_{j}}}{d_{i j}^{2}},
$$

where $C_{i}$ represents the sum of the city $i$ and other regional economic linkage. $P_{i}$ and $P_{j}$ are the populations of city $i$ and city $j$. In order to avoid the influence of county and countylevel cities on the population in prefecture-level administrative areas, we use the resident population data for the municipal districts in the sixth population census in 2010 to measure the population of cities. Finally, $d_{i j}$ is the geographic distance between city $i$ and $j$.

After calculating the two-dimensional data $(n * n)$ for the economic linkage between all cities, the economic linkage of each city was summed up and then ranked according to size. Table 13 reports the top 10 cities when it comes to centrality.

Based on the centrality ranking of each city, the sample was divided into three sections of 1-100, 100-200, and over 200 for the purposes of our sample regression. Model (1) in Table 14 reports the regression results of the 100 cities with the highest centrality ranking. Model (2) reports the regression results of the cities ranked 100-200. Model (3) shown in Table 14 reports the regression results of the cities ranked after 200. From model (1) and model (2), it can be seen that for the cities ranked 1-200 in centrality, the sign of market potential on firm productivity is significantly positive, which indicate that the improved market potential brought by the development of highway has a significant positive impact on firm productivity. The coefficient of market potential in model (3) turns from positive to negative, suggesting a negative impact on firm productivity. By contrast, for cities with lower degrees of centrality, highway construction may have a negative impact.

6.4. Why Is It Happening? Test of Core-Periphery Effects in Ex Ante Asymmetric Markets. For cities with different centrality rankings, highway construction has different effects on 
TABLE 13: Top 10 cities, ranked according to degrees of centrality.

\begin{tabular}{lc}
\hline City & Rank \\
\hline Shanghai & 1 \\
Guangzhou & 2 \\
Beijing & 3 \\
Foshan & 4 \\
Chongqing & 5 \\
Shenzhen & 6 \\
Dongguan & 7 \\
Tianjin & 8 \\
Wuhan & 9 \\
Xi'an & 10 \\
\hline
\end{tabular}

TABLE 14: Result of sample regression according to the relative centrality of Chinese cities.

\begin{tabular}{lccc}
\hline \multirow{4}{*}{ Variables } & $(1)$ & $(2)$ & $(3)$ \\
& TFP & TFP & TFP \\
& $1-100$ & $100-200$ & $>200$ \\
\hline \multirow{2}{*}{ MP } & $2.3060^{* * *}$ & $2.6203^{* * *}$ & $-0.2615^{* *}$ \\
& $(17.0725)$ & $(11.7148)$ & $(-2.4581)$ \\
Age & $0.0577^{* * *}$ & $0.0811^{* * *}$ & $0.0684^{* * *}$ \\
& $(26.6294)$ & $(22.4496)$ & $(12.4437)$ \\
Scale & $0.2386^{* * *}$ & $0.2063^{* * *}$ & $0.1652^{* * *}$ \\
& $(145.5082)$ & $(76.5766)$ & $(35.1294)$ \\
Export & -0.0011 & $0.0545^{* * *}$ & $0.0313^{* * *}$ \\
& $(-0.3906)$ & $(7.4845)$ & $(2.7186)$ \\
Own state & $-0.0898^{* * *}$ & $-0.0661^{* * *}$ & $-0.0899^{* * *}$ \\
& $(-10.7700)$ & $(-4.7287)$ & $(-4.7088)$ \\
GDP & $0.2209^{* * *}$ & $0.2024^{* * *}$ & 0.0003 \\
& $(21.7702)$ & $(18.7106)$ & $(0.0157)$ \\
R\&D & $0.0248^{* * *}$ & $0.0240^{* * *}$ & 0.0043 \\
& $(15.3662)$ & $(7.4162)$ & $(1.0621)$ \\
POP & $0.0047^{* * *}$ & $0.0150^{* * *}$ & $-0.0111^{* * *}$ \\
& $(3.8057)$ & $(7.1742)$ & $(-3.1779)$ \\
FDI & $0.0363^{* * *}$ & $-0.0130^{* * *}$ & $0.0128^{* * *}$ \\
& $(21.3190)$ & $(-6.0469)$ & $(4.4254)$ \\
Railway & $-0.1590^{* * *}$ & $0.0589^{* * *}$ & $0.0542^{* * *}$ \\
Constant & $(-20.9864)$ & $(6.2748)$ & $(5.7164)$ \\
Firm fixed effect & $-26.7496^{* * *}$ & $-30.3104^{* * *}$ & $3.7034^{* * *}$ \\
Time fixed effect & $(-17.5739)$ & $(-11.9787)$ & $(3.0528)$ \\
Observations & Yes & Yes & Yes \\
$R$-squared & $2,159,736$ & 615,938 & 251,372 \\
\hline & 0.0890 & 0.1265 & 0.0877 \\
\hline
\end{tabular}

Note. Standard errors are stated in parentheses below point estimates. ${ }^{* * *} 1 \%,{ }^{* *} 5 \%$, and ${ }^{*} 10 \%$ significance levels.

productivity. Because of the construction of the highway network, the passage between different regions is more convenient, enabling the migration of labor, capital, and other factors from a centrally weak city to a centrally strong city. Just as Faber [1] stated, there are "core-periphery effects of trade integration between ex ante asymmetric markets." To confirm the presence of these effects in our sample, we carried out an empirical test by replacing the explanatory variable in the mechanism regression with fixed asset investments and employment in city level. Our data come from the China City Statistical Yearbook. Table 15 reports the regression results.
TABLE 15: Regression result for core-periphery effects of asymmetric market integration.

\begin{tabular}{|c|c|c|c|c|}
\hline Varia & $\begin{array}{c}(1) \\
\text { Capital } \\
1-200\end{array}$ & $\begin{array}{c}(2) \\
\text { Capital } \\
>200 \\
\end{array}$ & $\begin{array}{c}(3) \\
\text { Labor } \\
1-200 \\
\end{array}$ & $\begin{array}{c}(4) \\
\text { Labor } \\
>200 \\
\end{array}$ \\
\hline MP & $\begin{array}{l}2.8826^{* * * *} \\
(25.1240)\end{array}$ & $\begin{array}{c}-1.2386^{* * *} \\
(-13.8694)\end{array}$ & $\begin{array}{c}0.2501^{* * *} \\
(2.7339)\end{array}$ & $\begin{array}{l}-0.0798 \\
(-0.8195)\end{array}$ \\
\hline Age & $\begin{array}{c}-0.0038^{* * *} \\
(-6.7015)\end{array}$ & $\begin{array}{c}0.0087^{* * *} \\
(2.8746)\end{array}$ & $\begin{array}{l}0.0872^{* * * *} \\
(58.7584)\end{array}$ & $\begin{array}{l}0.0685^{* * *} \\
(17.8215)\end{array}$ \\
\hline Scale & $\begin{array}{l}0.005 \\
(19.9\end{array}$ & $\begin{array}{l}-0.0 \\
(-1\end{array}$ & $\begin{array}{c}0.2847^{* * *} \\
(172.0069)\end{array}$ & $\begin{array}{l}0.2365^{* * *} \\
(44.9298)\end{array}$ \\
\hline Export & $\begin{array}{l}-0.00 \\
(-2.3\end{array}$ & $\begin{array}{l}-0.0 \\
(-1.2\end{array}$ & $\begin{array}{l}-0.1219^{* * *} \\
(-41.6744)\end{array}$ & $\begin{array}{l}-0.0090 \\
(-0.7582)\end{array}$ \\
\hline Own state & $\begin{array}{r}-0.02 \\
(-9.7\end{array}$ & & & $\begin{array}{c}0.1173^{* * *} \\
(8.5132)\end{array}$ \\
\hline GDP & $\begin{array}{l}0.567 \\
(129.4\end{array}$ & $\begin{array}{l}0.57 \\
(50 .\end{array}$ & $\begin{array}{l}-0.0018 \\
(-0.3714)\end{array}$ & $\begin{array}{l}-0.0228^{* *} \\
(-1.9926)\end{array}$ \\
\hline $\mathrm{R} \& \mathrm{D}$ & $\begin{array}{l}-0.01 \\
(-32 .\end{array}$ & $\begin{array}{r}-0.00 \\
(-4.1\end{array}$ & & \\
\hline POP & $\begin{array}{l}0.025 \\
(54.9\end{array}$ & $\begin{array}{l}0.0141^{* * *} \\
(10.6201)\end{array}$ & $\begin{array}{c}-0.0053^{* * *} \\
(-5.8211)\end{array}$ & $\begin{array}{c}-0.0093^{* * *} \\
(-3.4607)\end{array}$ \\
\hline FDI & $\begin{array}{l}0.086 \\
(162.7\end{array}$ & $\begin{array}{r}0.00 \\
(4.0\end{array}$ & $\begin{array}{l}-0.01 \\
(-12 .\end{array}$ & $\begin{array}{c}0.0006 \\
(0.3128)\end{array}$ \\
\hline Railway & $\begin{array}{c}-0.0966^{* * * *} \\
(-32.9382)\end{array}$ & $\begin{array}{c}-0.0156^{* * *} \\
(-6.9802)\end{array}$ & $\begin{array}{c}-0.0623^{* * *} \\
(-12.6149)\end{array}$ & $\begin{array}{c}0.0430^{* * *} \\
(4.6262)\end{array}$ \\
\hline Cons & $\begin{array}{c}-22.3370^{* * *} \\
(-17.2946)\end{array}$ & $\begin{array}{c}24.0051^{* * *} \\
(23.4137)\end{array}$ & $\begin{array}{l}-0.3966 \\
(-0.3834)\end{array}$ & $\begin{array}{c}3.3132^{* * *} \\
(2.9833)\end{array}$ \\
\hline $\begin{array}{l}\text { Firm fixed } \\
\text { effect }\end{array}$ & Yes & $\mathrm{Ye}$ & $\mathrm{Ye}$ & Yes \\
\hline $\begin{array}{l}\text { Time fixed } \\
\text { effect }\end{array}$ & $\mathrm{Y}$ & & $\mathrm{Y}$ & 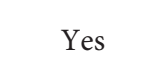 \\
\hline Observations & 2,775, & & 2,75 & 249 \\
\hline$R$-squared & 0.9012 & 0.7190 & 0.2936 & 0.2692 \\
\hline
\end{tabular}

Note. Standard errors are stated in parentheses below point estimates. ${ }^{* * *} 1 \%,{ }^{* *} 5 \%$, and ${ }^{*} 10 \%$ significance levels.

Model (1) in Table 15 reports the influence on capital and labor in the first 1-200 cities ranked according to degrees of centrality, and model (2) reports the result of the cities ranked lower than 200. We can conclude that highway construction has had a negative impact on the capital and labor of cities with fewer economic linkages, which indicate that the core-periphery effect is verified.

\section{Conclusion}

The construction of the highway network has had a profound impact on China's national economy. Studying the economic benefits of China's highway construction thus carries important theoretical and practical significance. The present paper cuts through the space-time compression effect and analyses how market potential is affected by highways, based on the travel time; in this way, we explore the impact of highway network construction on regional productivity, as well as the specific mechanisms by which that impact is achieved. Using the OD-MATRIX method, we calculate the highway travel time of 332 prefecture-level administrative units in China, and improve on previous accounts of market potential indicators. Specifically, we calculate the market potential brought about by highways 
from the perspective of time cost. Our empirical findings are as follows:

First, on average, the construction of the highway network in China has increased firm productivity. Because of the highway construction, the average travel time between each pair of cities we studied has decreased from 41.2 hours in 2000 to 19.2 hours. That said, in cities across the country, highway travel time presents a typical "core-peripheral" distribution pattern. With the Beijing-Tianjin-Hebei region, the Yangtze River Delta region, and the middle reaches of the Yangtze River as the core, it shows travel times gradually increase as one moves outward to the peripheral regions. On the whole, however, highway network construction has a significant positive impact on firm productivity growth. Therefore, the construction of China's highway network not only affords more convenient travel between regions but also constitutes an important reason for the long-term growth of China's economy.

Second, market potential is the intermediary mechanism by which the highway network affects firm productivity. Relying on Chen et al.'s [45] general formula for market potential, we used data for passenger capacity in various cities in China to estimate parameter $\beta$. In this way, we measured the market potential of cities across the country, finding that the market potential distribution of each prefecture-level city is similar to the distribution related to travel time. Market potential also presents a "core-periphery" distribution pattern. On the whole, market potential based on highways has a significant positive impact on firm productivity growth. Since market potential depends on the shortest travel time of highways between cities as well as the size of a given city, the impact of highway network on productivity is related not only to the mileage, density, and quality of highways in each city but also is to the size of each city.

Third, the impact of the highway network on firm productivity depends on the relative centrality of cities. Using the spatial gravity model, we carried out a sample regression according to cities' ranking for urban centrality. We found that the highways in high-centrality prefectures have a positive impact on productivity, while in cities ranked lower than 200 for centrality, highways have a negative impact on productivity. The reason for this pattern is that the highway network allows labor and capital to flow from a centrally weak city to a centrally strong city. According to their function, traffic flow, and quality, China divides road grades into expressways and first-class through fourth-class highways. The results of the sample regression show that an expressway is not required for each city. Instead, cities with low centrality can beneficially construct other, lower-grade highways, which carry lower replacement costs.

\section{Data Availability}

The research data used to support the findings of this study are available from the corresponding author upon request.

\section{Additional Points}

Highlights. (i) we match the Chinese industrial enterprise database and prefecture-level data to explore the influence of highway networks on enterprise productivity in China. (ii) we improve the calculation of market potential by estimating the dynamic parameter $\beta$. (iii) on average, the construction of highways promotes the productivity in China. (iv) highways have a positive impact in high-centrality cities but a negative impact in low-centrality cities.

\section{Conflicts of Interest}

No conflicts of interest exit in the submission of this manuscript, and it is approved by all authors for publication. The authors would like to declare on behalf of their coauthors that the work described was original research that has not been published previously, and is not under consideration for publication elsewhere, in whole or in part. All the authors listed have approved the manuscript that is enclosed.

\section{Authors' Contributions}

Yumei Lin and XiaoPeng Ji contributed equally to this work.

\section{Acknowledgments}

The authors are grateful for the financial support of the National Social Science Foundation of China (Grant No. 13BJY091) and the National Natural Science Foundation of China (Grant No. 71773083).

\section{References}

[1] B. Faber, "Trade integration, market size, and industrialization: evidence from China's National Trunk Highway System," The Review of Economic Studies, vol. 81, no. 3, pp. 1046-1070, 2014.

[2] N. Baum-Snow, J. V. Henderson, M. A. Turner, Q. Zhang, and L. Brandt, "Does investment in national highways help or hurt hinterland city growth?" Journal of Urban Economics, vol. 115, Article ID 103124, 2020.

[3] D. Donaldson and R. Hornbeck, "Railroads and American economic growth: a "market access" approach," Quarterly Journal of Economics, vol. 131, no. 2, pp. 799-858, 2016.

[4] A. Banerjee, E. Duflo, and N. Qian, On the Road: Access to Transportation Infrastructure and Economic Growth in China (No. w17897), National Bureau of Economic Research, Cambridge, MA, USA, 2012.

[5] A. Holl, "Highways and productivity in manufacturing firms," Journal of Urban Economics, vol. 93, pp. 131-151, 2016.

[6] X. Zhang, "Has transport infrastructure promoted regional economic growth?: with an analysis of the spatial spillover effects of transport infrastructure," Social Sciences in China, vol. 34, no. 02 , pp. 24-47, 2012, in Chinese.

[7] D. G. Janelle, "Central place development in a time-space Framework*," The Professional Geographer, vol. 20, no. 1, pp. 5-10, 1968.

[8] D. Donaldson, "Railroads of the Raj: estimating the impact of transportation infrastructure," The American Economic Review, vol. 108, no. 4-5, pp. 899-934, 2018.

[9] Z. Chen and K. E. Haynes, "Impact of high speed rail on housing values: an observation from the Beijing-Shanghai line," Journal of Transport Geography, vol. 43, pp. 91-100, 2015. 
[10] A. H. Munnell, "Why has productivity growth declined? Productivity and public investment," New England Economic Review, pp. 3-22, 1990.

[11] M. G. Boarnet, "Highways and economic productivity: interpreting recent evidence," Journal of Planning Literature, vol. 11, no. 4, pp. 476-486, 1997.

[12] M. N. Baily, R. J. Gordon, and R. M. Solow, "Productivity and the services of capital and labor," Brookings Papers on Economic Activity, vol. 1981, no. 1, pp. 1-65, 1981.

[13] E. Denison, Trends in American Economic Growth, Brookings Institution Press, Washington, DC, USA, 1985.

[14] Z. Griliches, "Productivity puzzles and R\&D: another nonexplanation," The Journal of Economic Perspectives, vol. 2, no. 4, pp. 9-21, 1988.

[15] D. A. Aschauer, "Is public expenditure productive?" Journal of Monetary Economics, vol. 23, no. 2, pp. 177-200, 1989.

[16] E. M. Gramlich, "Infrastructure investment: a review essay," Journal of Economic Literature, vol. 32, no. 3, pp. 1176-1196, 1994.

[17] P. Jiwattanakulpaisarn, R. B. Noland, and D. J. Graham, "Highway infrastructure and private output: evidence from static and dynamic production function models," Transportmetrica, vol. 7, no. 5, pp. 347-367, 2011.

[18] A. M. Pereira and J. M. Andraz, "Public highway spending and state spillovers in the USA," Applied Economics Letters, vol. 11, no. 12, pp. 785-788, 2004.

[19] J. Berechman, D. Ozmen, and K. Ozbay, "Empirical analysis of transportation investment and economic development at state, county and municipality levels," Transportation, vol. 33, no. 6 , pp. $537-551,2006$.

[20] K. Ozbay, D. Ozmen-Ertekin, and J. Berechman, "Contribution of transportation investments to county output," Transport Policy, vol. 14, no. 4, pp. 317-329, 2007.

[21] S. Chakrabarti, "Can highway development promote employment growth in India?" Transport Policy, vol. 69, no. OCT, pp. 1-9, 2018.

[22] X. Gao, X. Long, and G. Yang, "Transportation infrastructure and service industry development: evidence from county-level highways and enterprise data from the second economic census," Management World, vol. 2015, no. 8, pp. 81-96, 2015, in Chinese.

[23] X. Bu, T. Zhang, and S. Zhang, "Highway to prosperity: the impact of highway for efficiency of resource allocation in China," Management World, vol. 35, no. 5, pp. 44-63, 2019, in Chinese.

[24] R. Eisner, "Infrastructure and regional economic performance: comment," New England Economic Review, pp. 47-58, 1991.

[25] P. Evans and G. Karras, "Are government activities productive? Evidence from a panel of U.S. States," The Review of Economics and Statistics, vol. 76, no. 1, pp. 1-11, 1994.

[26] T. Garcia-Mila, T. J. Mcguire, and R. H. Porter, "The effect of public capital in state-level production functions reconsidered," The Review of Economics and Statistics, vol. 78, no. 1, pp. 177-180, 1996.

[27] C. Shirley and C. Winston, "Firm inventory behavior and the returns from highway infrastructure investments," Journal of Urban Economics, vol. 55, no. 2, pp. 398-415, 2004.

[28] S. Datta, Lessons from Nanoelectronics: A New Perspective on Transport, Vol. 1, World Scientific Publishing Company, , Hackensack, NJ, USA, 2012.

[29] G. Duranton and M. A. Turner, "Urban growth and transportation," The Review of Economic Studies, vol. 79, no. 4, pp. 1407-1440, 2012.
[30] E. Ghani, A. G. Goswami, and W. R. Kerr, "Highway to success: the impact of the Golden Quadrilateral project for the location and performance of Indian manufacturing," The Economic Journal, vol. 126, no. 591, pp. 317-357, 2016.

[31] N. Yu, M. De Jong, S. Storm, and J. Mi, "Spatial spillover effects of transport infrastructure: evidence from Chinese regions," Journal of Transport Geography, vol. 28, pp. 56-66, 2013.

[32] D. J. Graham, "Agglomeration, productivity and transport investment," Journal of Transport Economics and Policy, vol. 41, no. 3, pp. 317-343, 2007.

[33] A. Chandra and E. Thompson, "Does public infrastructure affect economic activity?" Regional Science and Urban Economics, vol. 30, no. 4, pp. 457-490, 2000.

[34] S.-m. Li and Y.-m. Shum, "Impacts of the national trunk highway system on accessibility in China," Journal of Transport Geography, vol. 9, no. 1, pp. 39-48, 2001.

[35] S. Lin, W. Ye, and L. Zhang, "Impact of time effect on location of manufacturing firms," China Industrial Economics, vol. 2018, no. 02, pp. 137-156, 2018, in Chinese.

[36] H. Nie, T. Jiang, and R. Yang, "The current situation and potential problems of Chinese industrial enterprise database," The Journal of World Economy, no. 5, pp. 142-158, 2012, in Chinese.

[37] L. Chen, "Reexploration on the use of database of Chinese industrial enterprises," Economic Review, vol. 6, 2018.

[38] L. Brandt, J. Van Biesebroeck, and Y. Zhang, "Creative accounting or creative destruction? Firm-level productivity growth in Chinese manufacturing," Journal of Development Economics, vol. 97, no. 2, pp. 339-351, 2012.

[39] H. Cai, Q. Liu, and G. Xiao, "Does competition encourage unethical behavior? The case of corporate profit hiding in China," Economic Journal, vol. 119, no. 4, pp. 764-795, 2009.

[40] Z. Jian, "Market distortion, inter-enterprises' resource allocation and productivity in manufacturing sector," China Industrial Economics, vol. 2011, no. 1, pp. 58-68, 2011, in Chinese.

[41] H. Nie and R. Jia, "Productivity and resource misplacement in Chinese manufacturing enterprises," The Journal of World Economy, no. 7, pp. 27-42, 2011, in Chinese.

[42] G. S. Olley and A. Pakes, "The dynamics of productivity in the telecommunications equipment industry," Econometrica, vol. 64, no. 6, pp. 1263-1297, 1996.

[43] C. D. Harris, "The, market as a factor in the localization of industry in the United States," Annals of the Association of American Geographers, vol. 44, no. 4, pp. 315-348, 1954.

[44] P. Krugman, A Dynamic Spatial Model (No. w4219), National Bureau of Economic Research, Cambridge, MA, USA, 1992.

[45] G. Chen, M. Correia, and J. D. A. E. Silva, “Accessibility indicators for regional economic development: an application to the regional distributive effects of high-speed rail in Spain," in Proceedings of the ERSA Conference PapersEuropean Regional Science Association, Lisbon, Portugal, August 2015.

[46] P. Rosik, M. Stępniak, and T. Komornicki, "The decade of the big push to roads in Poland: impact on improvement in accessibility and territorial cohesion from a policy perspective," Transport Policy, vol. 37, pp. 134-146, 2015.

[47] K. T. Geurs and J. R. Ritsema van Eck, "Accessibility measures: review and applications. Evaluation of accessibility impacts of land-use transportation scenarios, and related social and economic impact," RIVM rapport 408505006, 2001. 
[48] D. L. Hummels and G. Schaur, "Time as a trade barrier," The American Economic Review, vol. 103, no. 7, pp. 2935-2959, 2013.

[49] N. Limao and A. J. Venables, "Infrastructure, geographical disadvantage, transport costs, and trade," The World Bank Economic Review, vol. 15, no. 3, pp. 451-479, 2001.

[50] Y. Yi and E. Kim, "Spatial economic impact of road and railroad accessibility on manufacturing output: inter-modal relationship between road and railroad," Journal of Transport Geography, vol. 66, pp. 144-153, 2018.

[51] P. A. Geroski, “An applied econometrician's view of large company performance," Review of Industrial Organization, vol. 13, no. 3, pp. 271-294, 1998.

[52] E. Mansfield, "Rates of return from industrial research and development," The American Economic Review, vol. 55, no. 12, pp. 310-322, 1965.

[53] D. Puga, "The magnitude and causes of agglomeration economies," Journal of Regional Science, vol. 50, no. 1, pp. 203-219, 2010.

[54] W. Chung, W. Mitchell, and B. Yeung, "Foreign direct investment and host country productivity: the American automotive component industry in the 1980s," Journal of International Business Studies, vol. 34, no. 2, pp. 199-218, 2003.

[55] H. Görg and D. Greenaway, "Much ado about nothing? Do domestic firms really benefit from foreign direct investment?" The World Bank Research Observer, vol. 19, no. 2, pp. 171-197, 2004.

[56] Y. Lin, "Travel costs and urban specialization patterns: evidence from China's high speed railway system," Journal of Urban Economics, vol. 98, pp. 98-123, 2017.

[57] B. Liu, P. Wu, and Y. Liu, "Transportation infrastructure and the increase in TFP in China:spatial econometric analysis on provincial panel data," China Industrial Economics, vol. 2010, no. 3, pp. 54-64, 2010.

[58] J. D. Angrist and J. Pischke, "The credibility revolution in empirical economics: how better research design is taking the con out of econometrics," The Journal of Economic Perspectives, vol. 24, no. 2, pp. 3-30, 2014.

[59] D. Staiger and J. H. Stock, "Instrumental variables regression with weak instruments," Econometrica, vol. 65, no. 3, pp. 557-586, 1997.

[60] J. Eaton and S. Kortum, "Technology, geography, and trade," Econometrica, vol. 58, no. 3, pp. 1-23, 2002.

[61] A. B. Bernard, J. B. Eaton, J. B. Jensen, and S. Kortum, "Plants and productivity in international trade," American Economic Review, vol. 93, no. 4, pp. 1268-1290, 2003.

[62] W. Christaller, Die Zentralen Orte in Süddeutschland (The Central Places in Southern Germany), Gustav Fischer, Jena, Germany, 1933.

[63] R. S. Burt, "Positions in networks," Social Forces, vol. 55, no. 1, pp. 93-122, 1976.

[64] A. S. Alderson and J. Beckfield, "Power and position in the world city system," American Journal of Sociology, vol. 109, no. 4, pp. 811-851, 2004.

[65] D. R. Meyer, “The world system of cities: relations between international financial metropolises and South American cities," Social Forces, vol. 64, no. 3, pp. 553-581, 1986. 